\title{
3-Phosphoglycerate Dehydrogenase, a Key Enzyme for L-Serine Biosynthesis, Is Preferentially Expressed in the Radial Glia/Astrocyte Lineage and Olfactory Ensheathing Glia in the Mouse Brain
}

\author{
Miwako Yamasaki, ${ }^{1}$ Keiko Yamada, ${ }^{1}$ Shigeki Furuya, ${ }^{2}$ Junya Mitoma, ${ }^{3}$ Yoshio Hirabayashi, ${ }^{2}$ and \\ Masahiko Watanabe ${ }^{1}$ \\ ${ }^{1}$ Department of Anatomy, Hokkaido University School of Medicine, Sapporo 060-8638, Japan, 2Neuronal Circuit \\ Mechanisms Research Group, The Institute of Physical and Chemical Research (RIKEN), Brain Science Institute, Wako, \\ Saitama 351-0198, Japan, and ${ }^{3}$ Glycobiology Program, The Burnham Institute, La Jolla, California 92037
}

L-Serine is synthesized from glycolytic intermediate 3-phosphoglycerate and is an indispensable precursor for the synthesis of proteins, membrane lipids, nucleotides, and neuroactive amino acids D-serine and glycine. We have recently shown that L-serine and its interconvertible glycine act as Bergmann gliaderived trophic factors for cerebellar Purkinje cells. To investigate whether such a metabolic neuron-glial relationship is fundamental to the developing and adult brain, we examined by in situ hybridization and immunohistochemistry the cellular expression of 3-phosphoglycerate dehydrogenase (3PGDH), the initial step enzyme for de novo L-serine biosynthesis in animal cells. At early stages when the neural wall consists exclusively of the ventricular zone, neuroepithelial stem cells expressed 3PGDH strongly and homogeneously. Thereafter, 3PGDH expression was downregulated and eventually disappeared in neuronal populations, whereas its high expression was transmitted to the radial glia and later to astrocytes in the gray and white matters. In addition, 3PGDH was highly expressed throughout development in the olfactory ensheathing glia, a specialized supporting cell that thoroughly ensheathes olfactory nerves. These results establish a fundamental link of the radial glia/astrocyte lineage and olfactory ensheathing glia to L-serine biosynthesis in the brain. We discuss this finding in the context of the hypothesis that 3PGDH expression in these glia cells contributes to energy metabolism in differentiating and differentiated neurons and other glia cells, which are known to be vulnerable to energy loss.

Key words: 3-phosphoglycerate dehydrogenase; L-serine; astrocyte; olfactory ensheathing glia; brain; mouse; development; immunohistochemistry; in situ hybridization
Emerging evidence indicates that the nonessential amino acid L-serine plays an essential role in neuronal development and function. It serves not only as a building block of proteins, but also as a precursor for syntheses of L-cysteine, phosphatidyl-Lserine, sphingolipids, nucleotides, and the neuromodulators D-serine and glycine (Snell, 1984; Stryer, 1995; Snyder and Kim, 2000). L-Serine metabolism in animal cells has been characterized well, and the de novo synthesis in the brain is thought to be important, because of its low permeability at the blood-brain barrier (Smith, 2000). L-Serine biosynthesis from a glycolytic intermediate 3-phosphoglycerate (i.e., phosphorylated pathway) involves three sequential reactions initiated by 3-phosphoglycerate dehydrogenase (3PGDH) (Ichihara and Greenberg, 1957; Snell, 1984). L-Serine is also converted from glycine by serine hydroxymethyltransferase. Indeed, these biosynthetic enzymes are widely distributed in various organs, including the brain, and are significantly upregulated in proliferating cells and neoplastic tissues

\footnotetext{
Received April 23, 2001; revised July 9, 2001; accepted July 20, 2001.

This investigation was supported in part by the Grant-in-Aid for Special Coordination Funds toward the Promotion of Science and Technology, and for Scientific Research on Priority Areas, provided by the Ministry of Education, Culture, Sports, Science, and Technology of Japan. This work was also supported by a grant from RIKEN, Brain Science Institute. We thank Hidemi Shimizu and Dr. Shin Nakagawa at Hokkaido University School of Medicine for their technical assistance.

Correspondence should be addressed to Masahiko Watanabe, Department of Anatomy, Hokkaido University School of Medicine, Sapporo 060-8638, Japan. E-mail: watamasa@med.hokudai.ac.jp.

Copyright (C) 2001 Society for Neuroscience $\quad 0270-6474 / 01 / 217691-14 \$ 15.00 / 0$
}

(Davis and Fallon, 1970). The phosphorylated pathway is considered to play a chief role in the de novo synthesis in various mammalian cells, and its physiological importance in the brain has been evidenced in inherited 3PGDH deficiency. Patients with this deficiency have reduced enzyme activities and exhibit marked decreases of L-serine and glycine concentrations in both plasma and cerebrospinal fluid (Jaeken et al., 1996; de Koning et al., 1998, 1999; Klomp et al., 2000). Consequently, they are afflicted with severe neurological disorders, i.e., congenital microcephaly, dysmyelination, intractable seizures, and psychomotor retardation.

In parallel with these findings, culture studies have shown independently that exogenously supplied L-serine promotes neuronal survival and differentiation of sensory ganglia, hippocampal neurons, and cerebellar Purkinje cells (Savoca et al., 1995; Mitoma et al., 1998a; Furuya et al., 2000). Similar neurotrophic effects are observed for glycine (Mitoma et al., 1998b; Furuya et al., 2000). Analysis of the lipid composition demonstrates that exogenous L-serine is necessary for phosphatidyl-L-serine and sphingolipid biosyntheses in cultured hippocampal neurons, when they are maintained under a glia-free condition (Mitoma et al., 1998b). Enrichment in astrocyte-conditioned media suggests that astrocytes are the source of neurotrophic L-serine (Mitoma et al., 1998a; Furuya et al., 2000; Verleysdonk and Hamprecht, 2000). In support of this notion, cerebellar Purkinje cells have no detectable transcripts and immunoreactivity for 3PGDH, whereas its high contents are observed in the Bergmann glia (Furuya et al., 

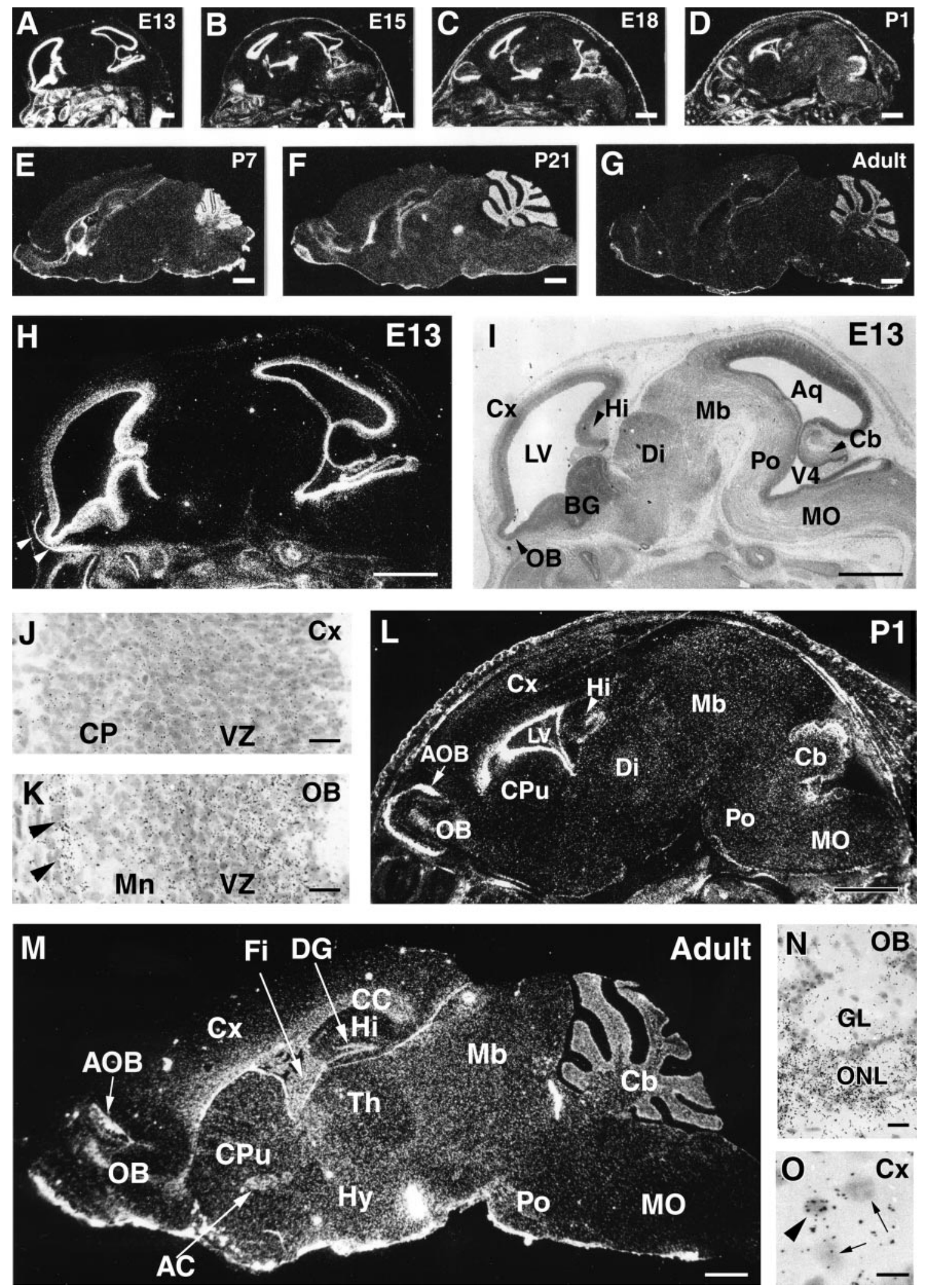

Figure 1. In situ hybridization showing 3PGDH mRNA expression in the developing mouse brain. $A-G$, X-ray film macroautoradiography of parasagittal brain sections at E13 $(A), \mathrm{E} 15(B), \mathrm{E} 18(C), \mathrm{P} 1(D), \mathrm{P} 7(E), \mathrm{P} 21(F)$, and adult $(G)$. All sections were processed for hybridization and washing in the same experiment and exposed to a single x-ray film. $H-O$, Emulsion microautoradiography at E13 $(H-K)$, P1 $(L)$, and adult $(M-O)$. For bright-field microscopy $(I-K, N$, and $O$ ), sections were counterstained with hematoxylin. In $H$ and $K$, arrowheads indicate a lining of 3PGDH mRNA on the surface of the olfactory bulb. In $O$, an arrowhead indicates a 3PGDH mRNA-positive cell having a small dark nucleus, whereas arrows indicate negative cells having a pale, large nucleus. In all photographs, the rostral is to the left, and the dorsal is to the top. Scale bars: $A-I, L, M, 1 \mathrm{~mm} J, K$, $N, 20 \mu \mathrm{m} ; O, 10 \mu \mathrm{m}$. $A C$, Anterior commissure; $A O B$, accessory olfactory bulb; $A q$, aqueduct; $A s$, astrocytic process; $A t$, axon terminal; $A x$, axon; $B G$, basal ganglia; $C A 1$ and $C A 3, \mathrm{CA} 1$ and $\mathrm{CA} 3$ regions of the Ammon's horn; $\mathrm{Cb}$, cerebellum; $C C$, corpus callosum; $C P$, cortical (Figure legend continues.) 
2000), a native astrocyte that associates structurally and functionally with Purkinje cells (Altman, 1972; Grosche et al., 1999; Yamada et al., 2000). On the basis of these findings, we have proposed that the differential expression profile of 3PGDH between neurons and astrocytes is the underlying mechanism of the neurotrophic action by L-serine (Furuya et al., 2000).

We attempted to ascertain whether such a neuron-glial relationship in terms of 3PGDH expression can be generalized in the developing and mature brain. Here we show in the mouse brain that $3 \mathrm{PGDH}$ is expressed strongly in neuroepithelial stem cells. After neurogenesis, however, its expression is lost from neurons and becomes concentrated in the radial glia/astrocyte lineage and olfactory ensheathing glia, both of which associate intimately with differentiating and regenerating neuronal elements.

\section{MATERIALS AND METHODS}

Animals and section preparation. Under deep pentobarbital anesthesia $(100 \mathrm{mg} / \mathrm{kg}$ of body weight, i.p.), brains of the C57BL/6J mouse were obtained at embryonic day (E) 11, E13, E15, and E18, postnatal day (P) 1, P7, P14, and P21, and adult (2-4 months). The day after overnight mating was counted as E0. For isotopic in situ hybridization, brains were freshly obtained and frozen immediately with powdered dry ice. Frozen sections $(20 \mu \mathrm{m}$ in thickness) were prepared on a cryostat (CM1900; Leica, Nussloch, Germany) and mounted on glass slides precoated with 3-aminopropyltriethoxysilane (Sigma, St. Louis, MO). For immunofluorescence, fetal brains were immersed overnight in Bouin's fixative (a mixture of saturated picric acid, $15 \mathrm{ml}$, formaldehyde solution, $5 \mathrm{ml}$, and acetic acid, $1 \mathrm{ml}$ ) and embedded in paraffin wax after dehydration using graded alcohols. Paraffin sections $(4 \mu \mathrm{m})$ were prepared on a sliding microtome (SM2000R, Leica). For immunofluorescence and nonisotopic in situ hybridization, postnatal brains were perfused transcardially with $4 \%$ paraformaldehyde in $0.1 \mathrm{M}$ sodium phosphate buffer (PB), $\mathrm{pH}$ 7.2, for the preparation of paraffin sections, cryostat sections, and microslicer sections $(50 \mu \mathrm{m}$; VT1000S, Leica). For immunoelectron microscopy, adult brains were perfused transcardially with $4 \%$ paraformaldehyde $/ 0.1 \%$ glutaraldehyde in $0.1 \mathrm{M} \mathrm{PB}, \mathrm{pH} 7.2$, for the preparation of microslicer sections.

In situ hybridization. To synthesize oligonucleotide probes for mouse 3PGDH mRNA, we cloned mouse 3PGDH cDNA from the brain cDNA library and sequenced. Probe regions of two nonoverlapping antisense oligonucleotides were 5'-TACTCATCAGTGACAGCCTGGACCCCTGCTGCCGGAAGATCCTGC-3' and 5'-TACAGCTGCTGTCCTACCAAACCTCCATGGTGTCTGACGGAGAGC-3', which correspond to nucleotide residues $94-138$ or 1537-1581, respectively, of rat 3PGDH cDNA (Achouri et al., 1997) (GenBank accession no. X97772). Data presented in Figure 1 were obtained with the latter probe. They were labeled with ${ }^{35} \mathrm{~S}$-dATP to a specific activity of $0.5 \times 10^{9} \mathrm{dpm} / \mu \mathrm{g}$ DNA, using terminal deoxyribonucleotidyl transferase (BRL, Bethesda, MD). Fresh-frozen sections were treated at room temperature as follows: $4 \%$ paraformaldehyde in $0.1 \mathrm{M} \mathrm{PB}$ for $10 \mathrm{~min}, 2 \mathrm{mg} / \mathrm{ml}$ of glycine in PBS for $10 \mathrm{~min}, 0.25 \%$ acetic anhydride in $0.1 \mathrm{M}$ triethanolamine- $\mathrm{HCl}, \mathrm{pH} 8.0$, for $10 \mathrm{~min}$, and prehybridization buffer for $1 \mathrm{hr}$. Prehybridization buffer contains $50 \%$ formamide, $50 \mathrm{~mm}$ Tris- $\mathrm{HCl}$, pH 7.5, 0.02\% Ficoll, $0.02 \%$ polyvinylpyrrolidone, $0.02 \%$ bovine serum albumin, $0.6 \mathrm{M} \mathrm{NaCl}, 0.25 \%$ SDS, $200 \mu \mathrm{g} / \mathrm{ml}$ of tRNA, $1 \mathrm{~mm}$ EDTA, and $10 \%$ dextran sulfate. Hybridization was performed at $42^{\circ} \mathrm{C}$ for $10 \mathrm{hr}$ in the prehybridization buffer supplemented with $10,000 \mathrm{cpm} / \mu \mathrm{l}$ of ${ }^{35} \mathrm{~S}$-labeled oligonucleotide probes and $0.1 \mathrm{M}$ dithiothreitol. Slides were washed twice at $55^{\circ} \mathrm{C}$ in $0.1 \times$ SSC containing $0.1 \%$ sarcosyl for $40 \mathrm{~min}$. Slides were exposed to Hyperfilm- $\beta$ max (Amersham, Arlington Heights, IL) for 3 weeks and then dipped in NTB-2 nuclear track emulsion (Kodak, Rochester, NY) for 1-2 months. Photographs were taken with an SZH dark-field microscope (Olympus, Tokyo, Japan).

For non-isotopic in situ hybridization, digoxigenin (DIG)-labeled cRNA probes were prepared to detect proteolipid protein (PLP) mRNA. A full-length mouse PLP cDNA subcloned into the Bluescript SK $(+)$ plasmid vector was generously provided by Prof. K. Ikenaka (National Institute for Physiological Sciences). Using the linearized plasmid, in vitro transcription was performed using T7 or T3 RNA polymerase. Sense and antisense transcripts were alkali digested to an average length of 150-200 bases. Procedures for non-isotopic in situ hybridization were the same as for isotopic, except that hybridization was performed at $50^{\circ} \mathrm{C}$. After washing, sections were incubated with alkaline phosphatase-linked sheep anti-DIG antibody (Boehringer Mannheim, Mannheim, Germany). Hybridizing signals were visualized with a fluorogenic phosphatase substrate, 2-hydroxy-3-naphtholic acid-2'-phenylanilide phosphate Fluorescent Detection Set (Boehringer Mannheim).

Antibody preparation. Polyclonal antibodies to $3 \mathrm{PGDH}$ were raised against a full-length rat 3PGDH, which had been expressed using a pET3d plasmid vector and a BL21(DE3)pLys stain of Escherichia coli (Stratagene, La Jolla, CA). Because bacterially expressed 3PGDH was insoluble, it was first solubilized in $25 \mathrm{~mm}$ Tris- $\mathrm{HCl}(\mathrm{pH} 7.5) / 8 \mathrm{M}$ urea and then purified by DEAE-5PW high-performance liquid chromatography under a linear gradient from $25 \mathrm{~mm}$ Tris- $\mathrm{HCl}(\mathrm{pH} 7.5) / 8 \mathrm{M}$ urea to $25 \mathrm{~mm}$ Tris (pH 7.5)/1 M NaCl/8 $\mathrm{m}$ urea. By stepwise dialysis to PBS, a small amount of soluble 3PGDH was obtained and used for immunization and affinity gel preparation. 3PGDH was emulsified with Freund's complete adjuvant (Difco, Detroit, MI) and injected subcutaneously into a female New Zealand White rabbit (70 $\mu \mathrm{g}$ of 3PGDH per injection) and a Hartley guinea pig ( $30 \mu \mathrm{g}$ per injection) at intervals of $2-4$ weeks. Two weeks after the sixth injection, the immunoglobulin fraction was purified from antisera using protein-G Sepharose (Pharmacia Biotech AB, Uppsala, Sweden). Immunoglobulins specific to 3 PGDH were affinity purified using 3PGDH coupled to CNBr-activated Sepharose 4B (Pharmacia Biotech AB). Rabbit anti-3PGDH antibody was used for most experiments with additional use of the guinea pig antibody when necessary for double immunofluorescence.

Immunoblot. Brains of the adult C57BL/6J mouse were homogenized in $10 \mathrm{vol}$ of buffer containing $10 \mathrm{~mm}$ Tris- $\mathrm{HCl}, \mathrm{pH}$ 7.2, 5 mM EDTA, 0.32 $\mathrm{M}$ sucrose, and $1 \mathrm{~mm}$ phenylmethylsulfonyl fluoride, and centrifuged at $700 \times g$ for $10 \mathrm{~min}$ to obtain a post-nuclear fraction. Protein concentration was determined by the Lowry's method (Lowry et al., 1951). Ten micrograms of protein samples were fractionated by $10 \%$ SDSpolyacrylamide gel and electroblotted onto a nitrocellulose membrane (Schleicher \& Schuell, Dassel, Germany). Blotted membrane was incubated with affinity-purified anti-3PGDH antibody at $1 \mu \mathrm{g} / \mathrm{ml}$ in PBS containing $0.1 \%$ Tween 20 and $0.5 \%$ skimmed milk, and visualized with an ECL chemiluminescence detection system (Amersham).

Immunohistochemistry. All immunohistochemical incubations were performed at room temperature. For light-microscopic immunoperoxidase, paraffin sections were incubated with $10 \%$ normal goat serum for 20 $\mathrm{min}$, rabbit anti-3-PGDH antibody $(0.2-0.5 \mu \mathrm{g} / \mathrm{ml})$ overnight, biotinylated goat anti-rabbit IgG for $1 \mathrm{hr}$, and streptavidin-peroxidase complex for $30 \mathrm{~min}$, using a Histofine SAB-PO(R) kit (Nichirei Corporation, Tokyo, Japan). Immunoreaction was visualized with 3,3'-diaminobenzidine (DAB). For immunofluorescence, sections immunoreacted with rabbit or guinea pig anti-3PGDH antibody overnight $(1 \mu \mathrm{g} / \mathrm{ml}$ for microslicer and $2 \mu \mathrm{g} / \mathrm{ml}$ for paraffin sections) were incubated with FITCor Cy3-conjugated secondary antibody for $2 \mathrm{hr}$ (Jackson ImmunoResearch, West Grove, PA). For double immunofluorescence, we used mouse anti-MAP2 antibody $(4 \mu \mathrm{g} / \mathrm{ml}$ for microslicer and $8 \mu \mathrm{g} / \mathrm{ml}$ for paraffin sections; Boehringer Mannheim), mouse anti-GFAP antibody (1 $\mu \mathrm{g} / \mathrm{ml}$ for microslicer sections; Boehringer Mannheim), rabbit antimicroglial response factor-1 (MRF-1) $(2 \mu \mathrm{g} / \mathrm{ml}$ for microslicer sections) (Tanaka et al., 1998), mouse anti-GAP-43 antibody $(1 \mu \mathrm{g} / \mathrm{ml}$ for paraffin

plate; $C P u$, caudate-putamen; $C x$, cerebral cortex; $D G$, dentate gyrus; $D i$, diencephalon; $D s$, dendritic spine; duc, dense undercoating at the node of Ranvier; $E G L$, external granular layer; End, capillary endothelial cell; $E P L$, external plexiform layer; $f$, intermediate filament; $F i$, fimbria; $G L$, glomerular layer; $g l$, olfactory glomerulus; $G r$, granule cell layer; $H i$, hippocampus; $h$, hilus of the dentate gyrus; $H y$, hypothalamus; im, inner mesaxons; $I P L$, internal plexiform layer; $I Z$, intermediate zone; $L V$, lateral ventricle; $M b$, midbrain; $M C L$, mitral cell layer; $M n$, mantle zone; $M o$, molecular layer; $M O$, medulla oblongata; $M Z$, marginal zone; $n$, nucleus of neurons; $N d$, node of Ranvier; $O B$, main olfactory bulb; om, outer mesaxons; $O N L$, olfactory nerve layer; $P N d$, paranodal cytoplasmic loop; $P o$, pons; $P P L$, preplate or primordial plexiform layer; $S P$, subplate; $T h$, thalamus; $V Z$, ventricular zone; $V 4$, fourth ventricle; I-VI, lamina I-VI of the cerebral cortex. Abbreviations apply to Figures 1-9. 
sections; Boehringer Mannheim), guinea pig anti-GLAST antibody (2 $\mu \mathrm{g} / \mathrm{ml}$ for paraffin sections) (Shibata et al., 1997), or mouse antibromodeoxyuridine (BrdU) (1:100; Becton Dickinson Biosciences, San Jose, CA). Some sections were counterstained with $1 \mu \mathrm{M}$ propidium iodide (Molecular Probes, Eugene, OR) for $10 \mathrm{~min}$. For double labeling by fluorescent in situ hybridization (PLP cRNA probe) and immunofluorescence (rabbit anti-3PGDH, $2 \mu \mathrm{g} / \mathrm{ml}$ ), cryostat sections were first processed for the former incubation and then subjected to the latter incubation. Photographs were taken with a confocal laser scanning microscope (Fluoview, Olympus).

For immunoelectron microscopy, microslicer sections immunoreacted overnight with rabbit anti-3-PGDH antibody $(0.1 \mu \mathrm{g} / \mathrm{ml})$ were processed for immunoperoxidase and DAB staining as above. Sections were further treated with $1 \%$ osmium tetroxide for $15 \mathrm{~min}, 2 \%$ uranyl acetate for $20 \mathrm{~min}$, dehydrated using graded alcohols, and embedded in Epon 812. Electron micrographs were taken with an H7100 electron microscope (Hitachi).

BrdU labeling. To label proliferating cells, adult mice were given a single injection of BrdU ( $75 \mathrm{mg} / \mathrm{kg}$ of body weight, i.p.; Wako, Osaka, Japan) in physiological saline. Two hours after the injection, they were anesthetized deeply with pentobarbital and perfused with $4 \%$ paraformaldehyde in $0.1 \mathrm{M}$ PB. For immunohistochemical detection of BrdUlabeled nuclei, microslicer sections were pretreated with $50 \%$ formamide $-2 \times \mathrm{SSC}$ at $65^{\circ} \mathrm{C}$ for $2 \mathrm{hr}$, followed by $15 \mathrm{~min}$ in $2 \times \mathrm{SSC}, 30 \mathrm{~min}$ in $2 \mathrm{~N} \mathrm{HCl}$ at $37^{\circ} \mathrm{C}$, and $10 \mathrm{~min}$ in $0.1 \mathrm{M}$ boric acid, $\mathrm{pH}$ 8.5. After three washes with PBS, double immunofluorescence for BrdU and 3PGDH was performed as described above.

\section{RESULTS}

\section{PGDH mRNA expression in developing and adult brains}

By in situ hybridization with ${ }^{35}$ S-labeled antisense oligonucleotide probe, 3PGDH mRNA expression in the mouse brain was pursued from E13 to the adult stage (Fig. 1). To show overall developmental changes, hybridized sections were first exposed to a single x-ray film (Fig. $1 A-G$ ). Then, they were subjected to emulsion microautoradiography to visualize the expression at the histological and cellular levels (Fig. $1 \mathrm{H}-\mathrm{O}$ ).

At E13, prominent signals for 3PGDH mRNA were detected in the ventricular zone (VZ) of various brain regions, whereas no significant transcripts were found in the mantle zone of most brain regions (Fig. $1 A, H-K$ ). 3PGDH mRNA was also detected along the surface of the olfactory bulb (Fig. $1 H, K$, arrowheads). Expression in the VZ was maintained at high levels during the late fetal stages (Fig. $1 B, C$ ) but was reduced substantially in early postnatal development (Fig. $1 D-F$ ). Reciprocally, dispersed clusters of hybridizing signals appeared in the mantle zone of each brain region; in general, the appearance started in the medulla oblongata at E13 (Fig. $1 A, H$ ), pons, and cerebellum at E15 (Fig. $1 B)$, midbrain and diencephalon at E15-E18, and telencephalon at E18-P1 (Fig. 1C,D,L). Thereafter, the number of hybridizing cells increased in the gray and white matters. In particular, remarkable upregulation occurred in the cerebellar cortex during the early postnatal period, reaching a maximum at P7 (Fig. 1E) and P14 (data not shown). On the other hand, prominent signals on the surface of the olfactory bulb were maintained until the adult stage.

In the adult brain, expression levels were lower than they were in the early postnatal brains (Fig. $1 G$ ). To show the detailed expression in the adult brain, a longer exposure (2 months) was used for emulsion-dipped sections (Fig. 1M-O). 3PGDH mRNA was dispersed widely in the gray and white matters of the adult brain, with the highest level in the olfactory nerve layer (ONL) of the main and accessory olfactory bulb (Fig. $1 M, N)$. Transcripts were also abundant in the dentate gyrus, cerebellar Purkinje cell layer, and white matter of various brain regions, including the corpus callosum, hippocampal fimbria, and anterior commissure. In the cerebral cortex, signals were detected in a subset of cells;

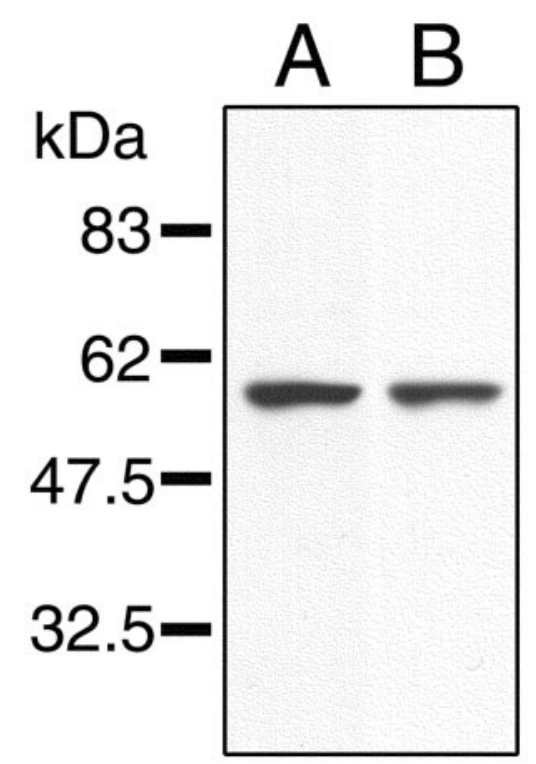

Figure 2. Immunoblot using rabbit $(A)$ and guinea pig $(B)$ anti-3PGDH antibodies. Both antibodies recognized a single protein band at $\sim 57 \mathrm{kDa}$. The size of marker protein is indicated to the left.

hybridization-positive cells were small cells having nuclei stained darkly with hematoxylin (Fig. 10, arrowhead), whereas medium to large cells with pale nuclei were not labeled (Fig. 10, small arrows), suggesting non-neuronal expression.

The specificity of the in situ hybridization was confirmed by similar distribution patterns with another nonoverlapping antisense oligonucleotide, and also by blank autoradiograms when hybridization was performed in the presence of excess amounts of unlabeled oligonucleotides (data not shown).

\section{Specificity of 3PGDH antibody and immunohistochemical signals}

Affinity-purified polyclonal antibodies to 3PGDH were produced in the rabbit and guinea pig. By immunoblot using adult mouse brain extracts, both antibodies recognized a single protein band at $57 \mathrm{kDa}$, as expected (Fig. 2). By immunohistochemistry, the antibody widely labeled the adult mouse brain, with higher levels on the surface of the olfactory bulb and in the cerebellar molecular layer (Fig. $3 A$ ). At E13, intense immunostaining was found in the VZ of various brain regions and on the surface of the olfactory bulb (Fig. 7A). The overall distribution of immunohistochemical signals was consistent with that of 3PGDH mRNA (Fig. 1). Furthermore, these immunohistochemical signals were abolished almost completely by use of the primary antibody preabsorbed with antigens $(100 \mu \mathrm{g} / \mathrm{ml})$ (Figs. $3 A, 7 A$, insets $)$. All of these results indicate the specificity of the antibody and immunohistochemistry.

\section{Cellular characterization in the adult brain}

Using the antibody, immunohistochemical characterization of 3PGDH-expressing cells was performed in the adult telencephalon (Figs. 3-6).

\section{Cerebral cortex}

In the cerebral cortex, immunoreactive cells were scattered from lamina I through VI (Fig. 3B). Strong 3PGDH immunoreactivity was detected in small cell bodies and perisomatic processes and also in numerous tiny puncta in the neuropil (Fig. $3 C$ ). By double 

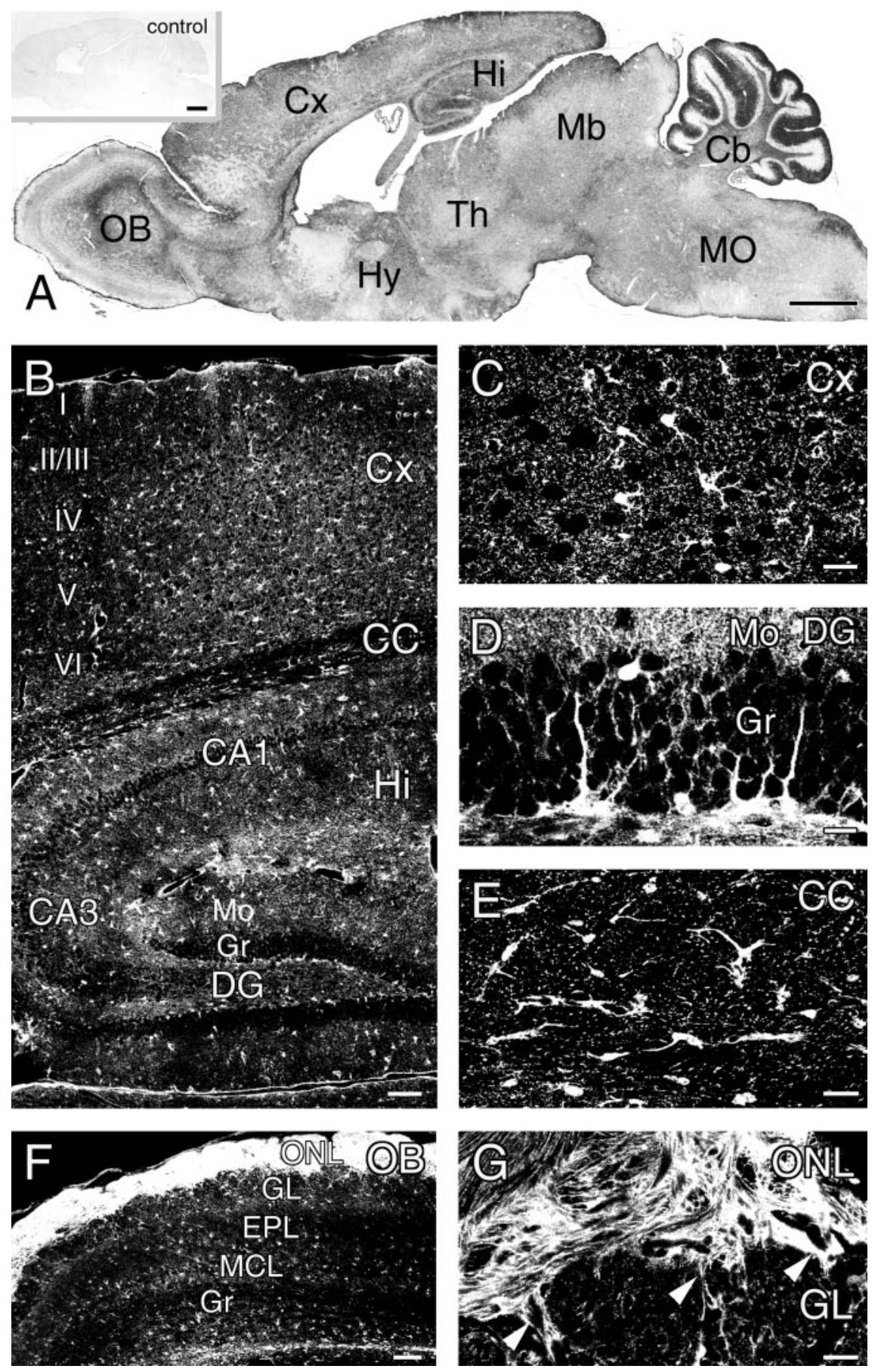

Figure 3. Immunoperoxidase $(A)$ and immunofluorescence $(B-G)$ for 3 PGDH in the adult mouse brain (parasagittal sections). $A$, Overall brain immunostaining. Inset, Control immunoperoxidase using 3PGDH antibody preabsorbed with the antigen. $B, F$, Lowpower confocal images over the cerebral cortex/hippocampus $(B)$ and the olfactory bulb $(F)$. High-power images are shown of the cerebral cortex $(C)$, dentate gyrus $(D)$, corpus callosum $(E)$, and olfactory nerve/ glomerular layers $(G)$. For other abbreviations, see Figure 1 legend. Scale bars: $A, 1 \mathrm{~mm} ; B, F, 100 \mu \mathrm{m}$; $C-E, G, 20 \mu \mathrm{m}$. immunofluorescence for 3PGDH (Fig. 4A, red) and MAP-2 (green), a marker for neuronal perikarya and dendrites, nonoverlapping patterns of immunostaining were clear; 3PGDHimmunopositive cell bodies and tiny puncta were distributed between MAP-2-positive neuronal somata and dendrites, and vice versa. Double immunofluorescence with glial fibrillary acidic protein (GFAP) (Fig. 4B, green), an astrocyte-specific intermediate filament, showed that 3PGDH (red) overlapped in perikarya and perisomatic processes, yielding a fused yellowish color. However, tiny puncta in the neuropil were predominantly labeled for 3PGDH, but not for GFAP. To clarify these punctate structures, immunoperoxidase electron microscopy was performed (see Fig. $6 A$ ). Immunoreaction products for $3 \mathrm{PGDH}$ were detected in lamellate structures surrounding synapses and dendrites, indicating the localization in astrocytic processes. Double immunofluorescence for MRF-1 (Fig. 4C, green), a microglia-specific $\mathrm{Ca}^{2+}$. binding protein (Tanaka et al., 1998), showed no significant overlap with 3PGDH (red). Therefore, in the cerebral cortex, $3 \mathrm{PGDH}$ is expressed exclusively in astrocytes, whereas neuronal and microglial expression, if any is present, is below the detection threshold by our present immunohistochemistry.

\section{Hippocampus}

Similarly to the cerebral cortex, 3PGDH in the hippocampus was detected in small cells extending irregular short processes and in neuropil puncta (Fig. $3 B, D$ ). In the dentate gyrus, cell bodies 

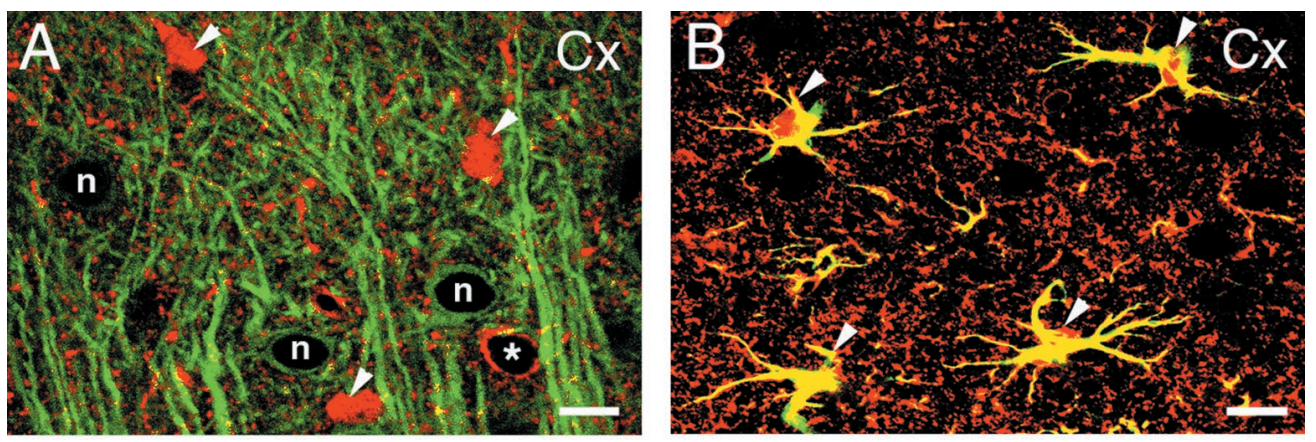

Figure 4. Double-labeling studies for
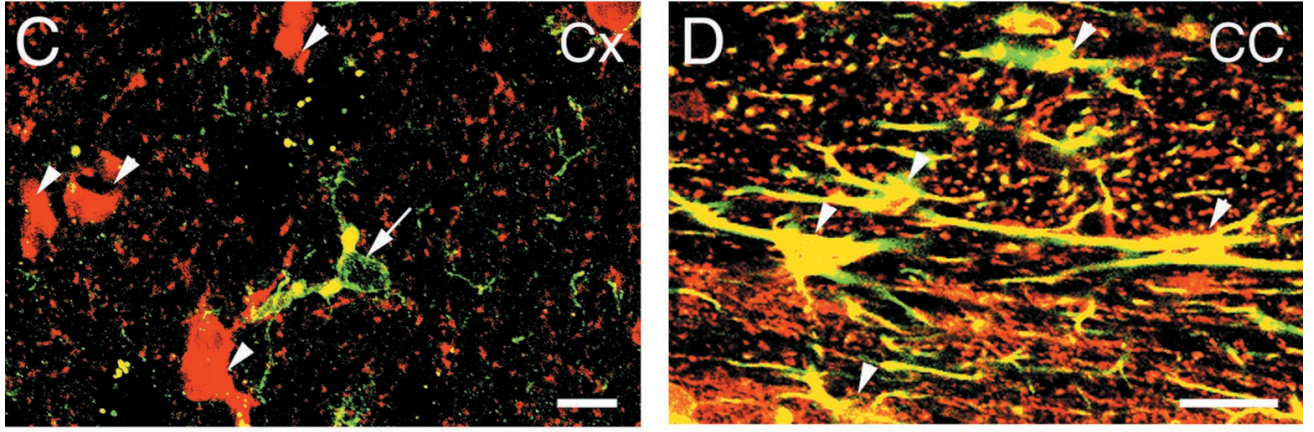

cytological and cytochemical characterization of 3PGDH-expressing cells in the telencephalon. $A-C$, Adult cerebral cortex $(C x)$. Double immunofluorescence for 3PGDH (red) and for neuronal marker MAP-2 $(A$, green $)$, astrocytic marker GFAP ( $B$, green), or microglial marker MRF-1 ( $C$, green). White arrowheads and asterisk indicate 3PGDH-positive somata or capillaries, respectively. A white arrow in $C$ indicates microglial cell body. $D$, Double immunofluorescence for 3PGDH (red) and GFAP (green) in the adult corpus callosum. $E-G$, Double-labeling for 3PGDH protein (green) and PLP mRNA (red) in the corpus callosum at P14. $E$ is a low-power view, and $F$ and $G$ are the same high-power images of merged view $(F)$ or separated view for 3PGDH immunolabeling $(G)$. Some PLP-positive cells $(F, G$, arrows) exhibit low to moderate immunoreactivity for 3PGDH. $H$, Adult olfactory bulb. Double immunofluorescence for 3PGDH (red) and GFAP ( green). For other abbreviations, see Figure 1 legend. Scale bars: $A-D, F, G, 10 \mu \mathrm{m} ; E, 100 \mu \mathrm{m} ; H$, $20 \mu \mathrm{m}$.
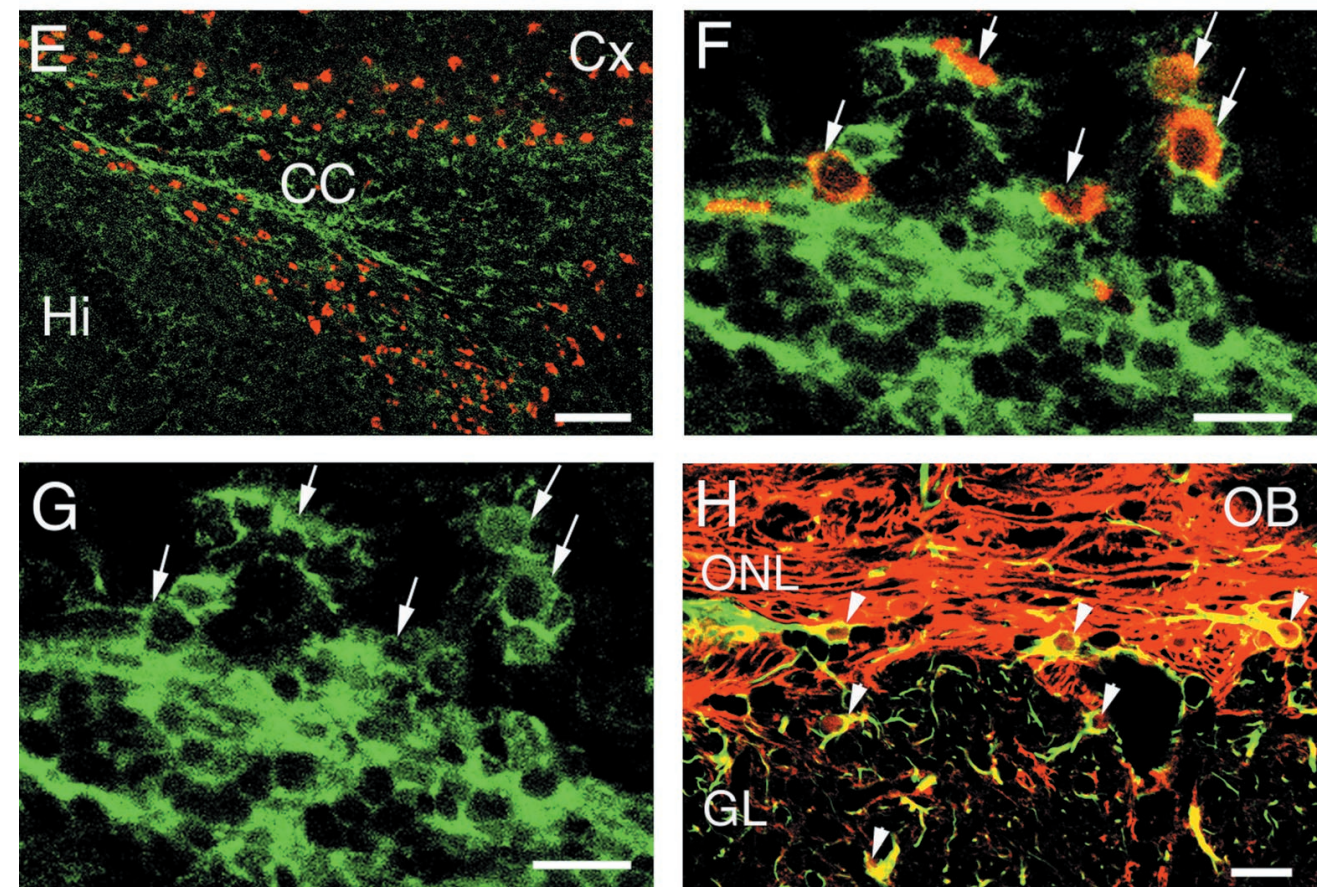

having intense 3PGDH immunoreactivity tended to be aligned in a monolayer along the inner surface of the granule cell layer (Fig. $3 D$ ). By double immunofluorescence, 3PGDH showed no overlap with MAP-2-positive neuronal elements (Fig. 5A, green). 3PGDH-positive cells were costained with GFAP; double-labeled cells in most hippocampal regions were multipolar in shape, whereas those in the inner surface of the granule cell layer extended long processes toward the molecular layer (Fig. $5 B$, green). However, some of 3PGDH-positive cells in the inner surface of the granule cell layer were negative to MAP-2 or GFAP. Because neural stem cells still reside there in the adult (Gage, 2000), we labeled proliferating cells by single injection of BrdU and examined the injected mouse brain at $2 \mathrm{hr}$ after injection. BrdU-incorporating cells were sparsely aligned in the inner surface of the granule cell layer (Fig. 5C, green), and all of the labeled cells showed prominent immunoreactivity for 3PGDH (red). In the hippocampus, 3PGDH is thus expressed in the GFAP-positive astrocytes and proliferating cells but not in neurons.

\section{Corpus callosum}

Numerous immunopositive cells were observed in the corpus callosum (Fig. 3B,E). 3PGDH overlapped well with GFAP in perikarya and perisomatic processes, which were often oriented parallel to callosal axons (Fig. 4D). Then we pursued the possibility of oligodendrocytic expression by double labeling: immu- 

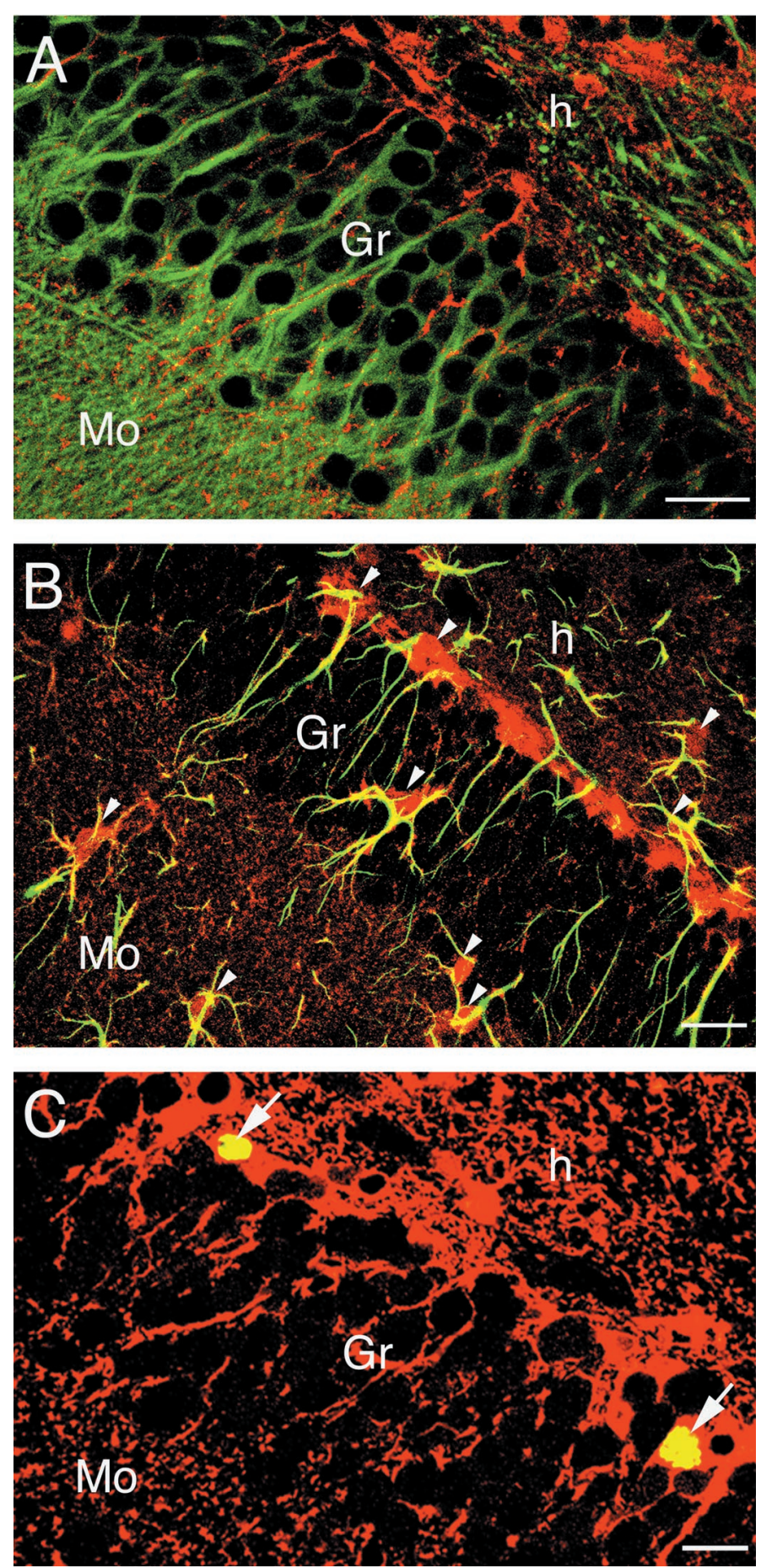

Figure 5. Double-labeling showing cellular characterization of 3PGDHpositive cells in the dentate gyrus of the adult hippocampus. Double immunofluorescence for 3PGDH (red) and MAP-2 (A, green), GFAP ( $B$, green), or BrdU ( $C$, green). In $B, 3 \mathrm{PGDH}-$ positive cell bodies (arrowheads) extend GFAP-positive processes. In $C$, BrdU-labeled cells (arrows) show intense immunoreactivity for 3PGDH. Scale bars: $A, B, 20 \mu \mathrm{m} ; C, 10 \mu \mathrm{m}$.

nofluorescence for 3PGDH (Fig. 4E-G, green) and fluorescent in situ hybridization for PLP mRNA (Fig. $4 E, F$, red). Because we examined the corpus callosum at P14, P21, and in the adult and obtained similar results, only the P14 results are presented (Fig. $4 E-G)$. Antisense PLP cRNA probe labeled cell bodies of some callosal cells (Fig. $4 E, F$ ), whereas the control sense probe gave no significant labeling (data not shown). When immunofluorescence for 3PGDH was overlaid, many callosal cells expressing PLP mRNA (Fig. $4 F, G$, arrows) were low to moderate for 3PGDH. In contrast, cells with more intense 3PGDH immunoreactivity were always detected in PLP mRNA-negative callosal cells (Fig. $4 F, G)$.

Cellular localization in the corpus callosum was further characterized by immunoelectron microscopy. 3PGDH was localized in thin processes surrounding synapses (Fig. 6B) and perivascular end-feet containing abundant intermediate filaments (Fig. 6C). Moreover, 3PGDH-positive processes were observed to surround the node of Ranvier (Fig. 6D) and the paranodal cytoplasmic loops of myelin sheaths (Fig. 6D, arrowheads). Axons and synapses were devoid of 3PGDH immunolabeling. Even with careful observation, however, we were not able to detect 3PGDH in oligodendrocytic elements, including compact myelin, outer and inner mesaxons, and paranodal cytoplasmic loops (Fig. 6B-D). On the basis of these findings, it is safe to judge that $3 \mathrm{PGDH}$ in the corpus callosum is abundantly localized in astrocytes, whereas its levels are low to moderate in perikarya of oligodendrocytes and nonexistent in their myelin-forming processes.

\section{Olfactory bulb}

Although 3PGDH immunoreactivity was distributed throughout the olfactory bulb, immunohistochemical patterns and intensity were different between the ONL and other olfactory regions (Fig. $3 F, G)$. In the ONL, levels of $3 \mathrm{PGDH}$ were quite intense, and labeled structures rarely overlapped with GFAP in the outer (superficial) part of the ONL (Fig. 4H). In the inner (or deeper) part of the ONL, 3PGDH-positive structures often entered into narrow interstices between olfactory glomeruli (Fig. 3G, arrowheads) and were sometimes detected in GFAP-positive astrocytes (Fig. 4H, arrowheads). Immunoelectron microscopy showed that 3PGDH was localized in thin processes that enfolded bundles of immunonegative olfactory nerve axons (Fig. $6 E$, arrowheads). In other olfactory regions, the morphology and cytochemical properties of 3PGDH-immunpositive cells resembled those in other telencephalic regions, i.e., multipolar cell shape and colabeling with GFAP (data not shown). Thus, in the olfactory bulb, 3-PGDH is localized in two glial populations: one is a common astrocyte, and the other is the olfactory ensheathing glia, a specialized supporting cell for olfactory nerves.

\section{Cellular characterization in the developing brain}

3PGDH expression in the developing mouse brain was then examined (Figs. 7-10). At E13, intense immunoreactivity was detected in almost all neuroepithelial cells that occupied the VZ of various brain regions, including the olfactory bulb (Fig. 7B), cerebral cortex (Fig. 7C), brainstem (Fig. 7D, pons), and cerebellum (Fig. $7 E$ ). Radial fibers, extending from the VZ toward the pial surface, were also labeled intensely. At E13, the radial fiber staining was most clearly visualized in the pons (Fig. $7 D$ ). Intense immunostaining was also detected on the surface of the olfactory bulb and its underlying peripheral tissues (Fig. 7B). To characterize the cellular expression during development, the cerebral cortex (Figs. 8,9) and olfactory bulb (see Fig. 10) were examined in detail by immunofluorescence.

\section{Cerebral cortex}

Two sets of parasagittal paraffin sections through the dorsomedial cortex were prepared. One set was processed for double labeling by propidium iodide (PI) nuclear counterstaining (Fig. 8A,C,E,G) 

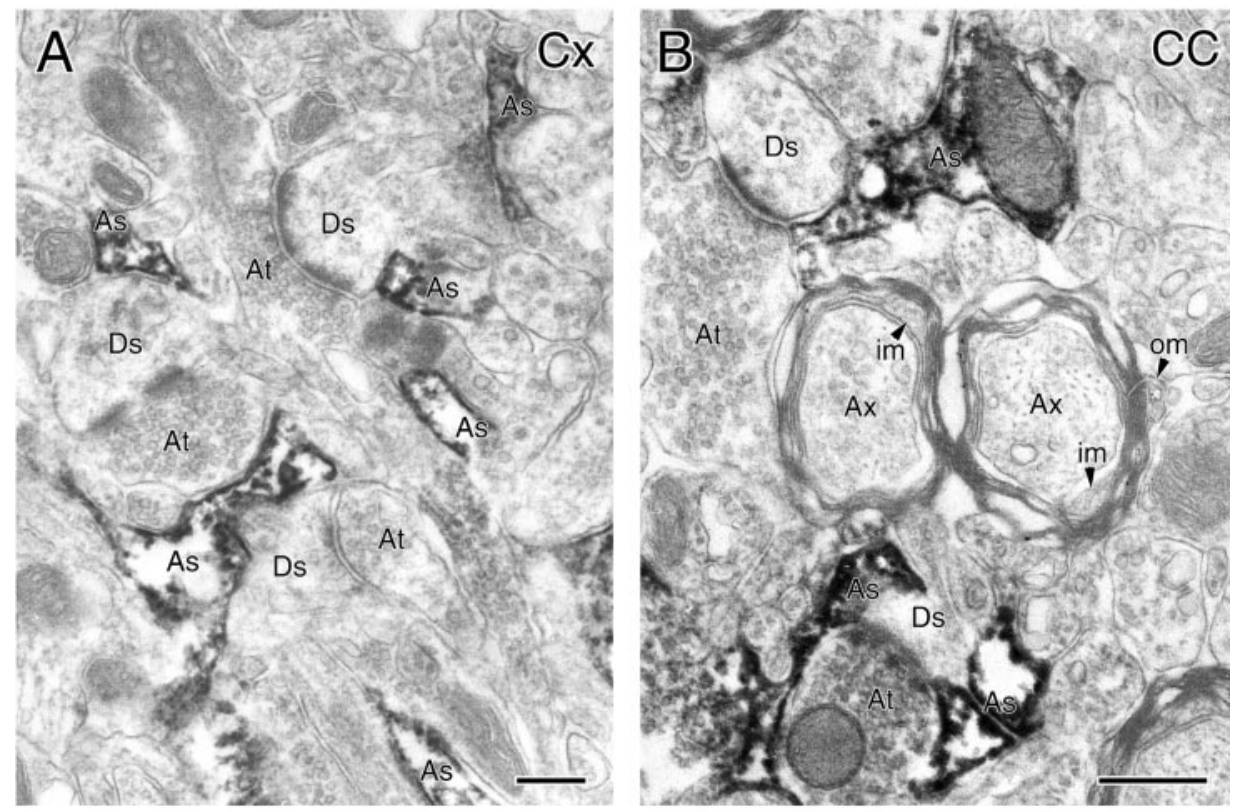

Figure 6. Immunoelectron microscopy showing the localization of 3PGDH in the adult cerebral cortex $(A)$, corpus callosum $(B-D)$, and olfactory nerve layer $(E)$. 3PGDH is detected in astrocytic processes $(A s)$, which are closely associated with synapses $(A, B, D)$, capillary endothelial cells $(C$, End $)$, paranodal cytoplasmic loops of myelin sheath $(D$, arrowheads), and the node of Ranvier $(D, N d)$. Abundant intermediate filaments $(f)$ are seen in the perivascular astrocyte in $C$. Note no significant immunolabeling in oligodendrocytic elements, i.e., outer mesaxons $(B, o m)$ and inner mesaxons $(B, i m)$, paranodal cytoplasmic loops $(D, P N d)$ and myelin sheaths. In the olfactory nerve layer $(E)$, thin processes immunolabeled for 3PGDH (arrowheads) enwrap bundles of unmyelinated olfactory nerve axons $(A x)$. For other abbreviations, see Figure 1 legend. Scale bars: $A, B, D, 0.2$ $\mu \mathrm{m} ; C, E, 1 \mu \mathrm{m}$.
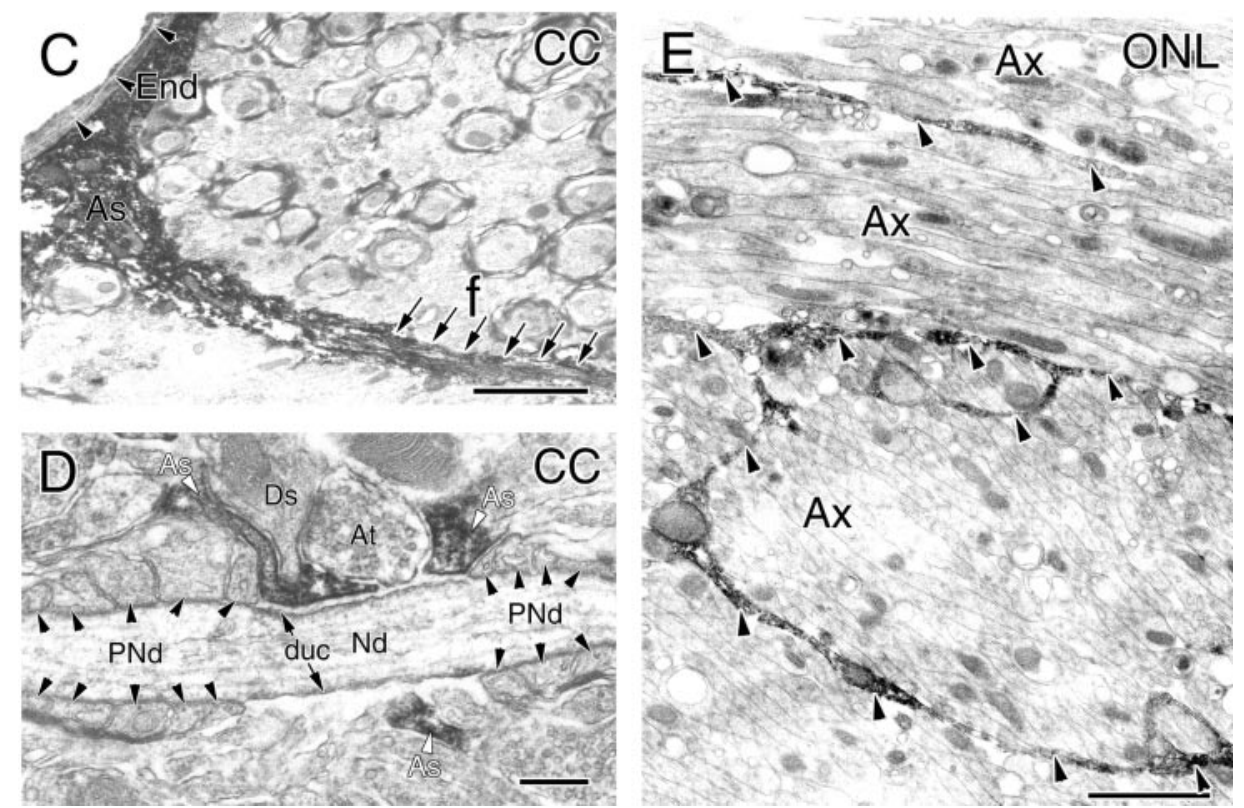

and 3PGDH immunofluorescence (Fig. $8 B, D, F, H$ ), whereas the other set was subjected to double immunofluorescence for $3 \mathrm{PGDH}$ (Fig. 9, red) and for MAP-2 (Fig. 9A-G, green) or glutamate transporter GLAST (Fig. 9H, green), a marker for radial glia cells (Shibata et al., 1997).

At E11, the wall of the telencephalic vesicle consisted exclusively of pseudostratified neuroepithelium or the VZ (Fig. 8A). At this stage, $3 \mathrm{PGDH}$ immunoreactivity was detected in almost all neuroepithelial cells (Fig. 8B). At E13, a thin cell-sparse layer appeared between the $\mathrm{VZ}$ and pial surface; this was judged to be the preplate or primordial plexiform layer, the first differentiating zone of the cortex (Fig. $8 C$ ). At this stage, uneven distribution of 3PGDH was evident (Fig. $8 D$ ): intense immunoreactivity was observed in the VZ, whereas the preplate was low or immunonegative. When double immunofluorescence was performed for 3PGDH and MAP-2, preplate cells were immunopositive for MAP-2 but lacked 3PGDH immunoreactivity (Fig. 9A,B). In- stead, 3PGDH labeling in the preplate was occasionally detected in fibrous structures running toward the pial surface (Fig. 9B, arrowhead).

On the basis of the patterns by nuclear staining and MAP-2 immunostaining, the preplate at E15 seemed to be differentiated into tri-laminar structures (Figs. $8 E, 9 C, D$ ): (1) a superficial cell-sparse layer, i.e., the marginal zone (MZ), (2) a middle cell-dense layer consisting of oval to ellipsoidal cells with low to moderate MAP-2 immunoreactivity, i.e., the cortical plate (CP), and (3) a deep thin layer consisting of round to cuboidal cells with intense MAP-2 immunoreactivity, i.e., the subplate. Moreover, the intermediate zone (IZ) was recognized as being the MAP2-immunonegative layer between the subplate and VZ (Fig. $9 C, D)$. At E15, intense 3PGDH immunoreactivity was observed in cells occupying the $\mathrm{VZ}$ and IZ (Fig. $8 F$ ), and they were negative to MAP-2 (Fig. 9C,D). In the MZ, CP, and subplate, intense $3 \mathrm{PGDH}$ immunoreactivity was detected in radial fibers 

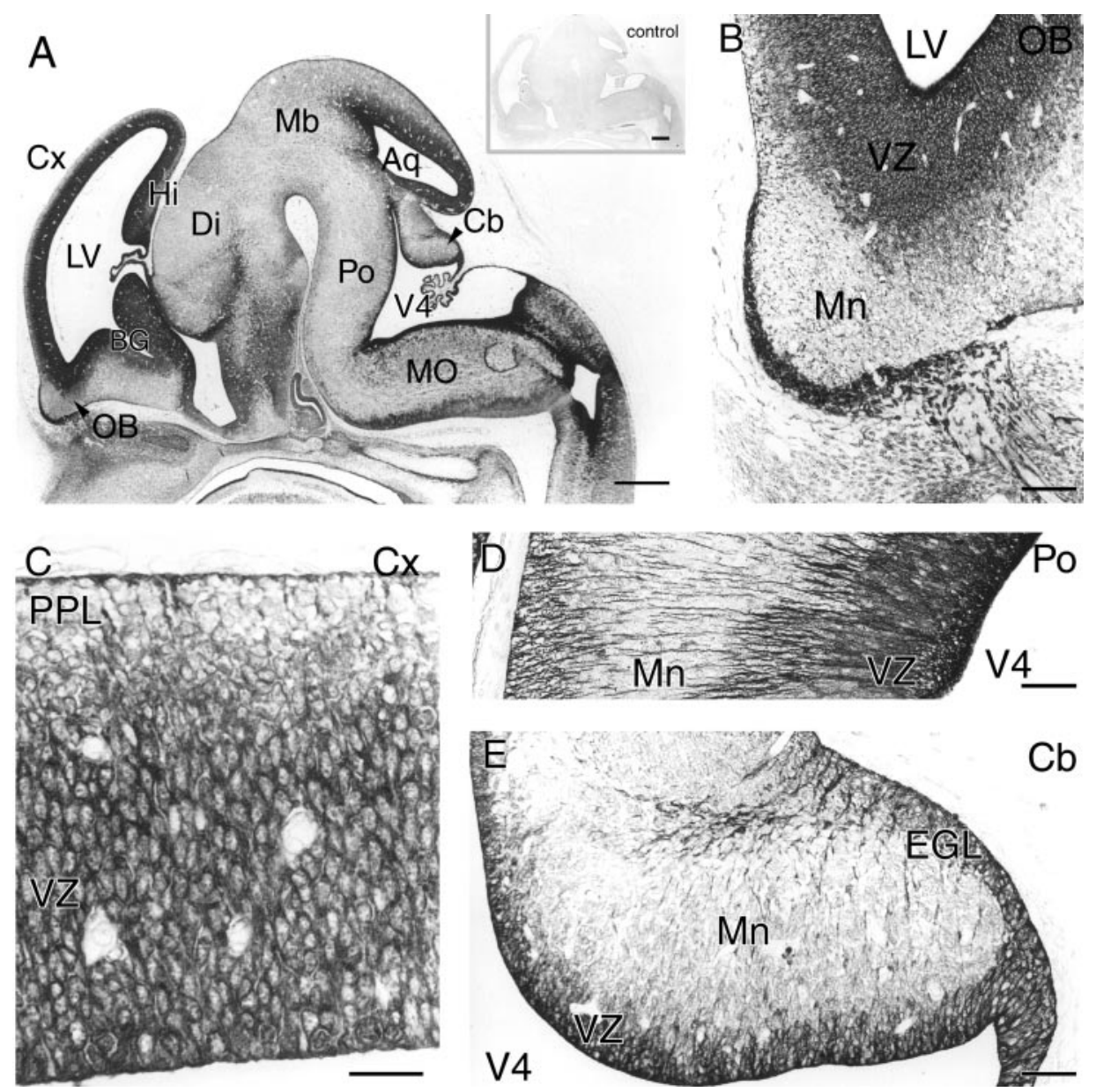

Figure 7. Immunoperoxidase for 3PGDH in the mouse brain at E13. A, The overall distribution. Inset shows control immunostaining with preabsorbed antibody. $B-E$, Higherpower views of the olfactory bulb $(B)$, cerebral cortex $(C)$, pons $(D)$, and cerebellum $(E)$. For other abbreviations, see Figure 1 legend. The rostral is to the left, and dorsal is to the top. Scale bars: $A, 0.5 \mathrm{~mm} ; B, D, E, 50$ $\mu \mathrm{m} ; C, 25 \mu \mathrm{m}$.
(Fig. 9D, arrowheads), which were immunonegative to MAP-2. On the other hand, CP neurons were weakly labeled for 3PGDH, whereas subplate neurons were immunonegative (Fig. 9D).

At E18, the CP was remarkably thickened, with concomitant reduction of the $\mathrm{VZ}$ (Fig. $8 G$ ). At this stage, two major trends became clear within the CP in terms of 3PGDH immunostaining. First, a superficial to deep gradient was notable in cellular staining for 3PGDH: superficial CP neurons were weakly immunopositive for $3 \mathrm{PGDH}$, whereas deeper $\mathrm{CP}$ neurons were similarly immunonegative to subplate neurons (Figs. $8 H, 9 E, F$ ). Second, a few elongated cells with intense 3PGDH immunoreactivity appeared in the CP. These cells often extended radial fibers toward the pial surface (Fig. 9F, arrowheads) and overlapped completely with GLAST (Fig. 9H). They were not labeled for MAP-2 but were closely apposed to MAP-2-positive neuronal cell bodies and processes (Fig. 9F, G). During the first postnatal week, 3PGDHpositive cells in the cerebral cortex became more numerous and astrocytic, on the basis of their morphological change from a unipolar to a multipolar shape and costaining with GFAP (data not shown).

\section{Olfactory bulb}

The developing olfactory bulb was examined from E11 to E18 (Fig. 10). By immunofluorescence for 3PGDH (Fig. 10A-D, green) and PI nuclear staining (red), the primordial olfactory bulb at E11 was observed as a slight bulging from the rostral telencephalic vesicle and was composed mostly of the VZ (Fig. 10A). Almost all neuroepithelial cells in the $\mathrm{VZ}$ were intense for
3PGDH. At E13, the mantle zone was formed above the VZ, and the cells were characterized by low or negative immunofluorescence for 3PGDH. From E15 to E18, the mantle zone differentiated into several layers (internal plexiform layer, mitral cell layer, and external plexiform layer), where intense 3PGDH immunostaining was detected in fibrous structures traversing these layers (Fig. 10B-D).

The ONL was also markedly developed during the embryonic stages (Fig. 10A-D). At E11, the surface of the primordial olfactory bulb was covered with a thin layer labeled for 3PGDH (Fig. $10 A$ ). From E13 to E18, the surface layer increased in thickness from the basal part of the olfactory bulb dorsally and was readily recognized to be the ONL (Fig. $10 B-D$ ). Concomitantly, the ONL remarkably increased the level of 3PGDH immunofluorescence and the number of 3PGDH-immunopositive cells. Streams of 3PGDH-positive cells were observed in peripheral tissues, running from the olfactory epithelium to the base of the olfactory bulb (Fig. 10 $A-D$, arrowheads). To characterize the immunoreactive cellular elements, double immunofluorescence was used at E18 (Fig. 10E-G). The ONL lacked MAP-2 immunoreactivity (Fig. 10E, green), resulting in no overlap with 3PGDH (red). Then, we chose growth cone-associated protein GAP-43 as a marker for growing olfactory nerves (Fig. 10F); 3PGDH-positive structures in the ONL and peripheral tissues (red) did not overlap with GAP-43-positive structures (green) but rather surrounded them elaborately. By double immunofluorescence for 3PGDH (Fig. 10G, red) and GLAST (green), they sometimes overlapped 


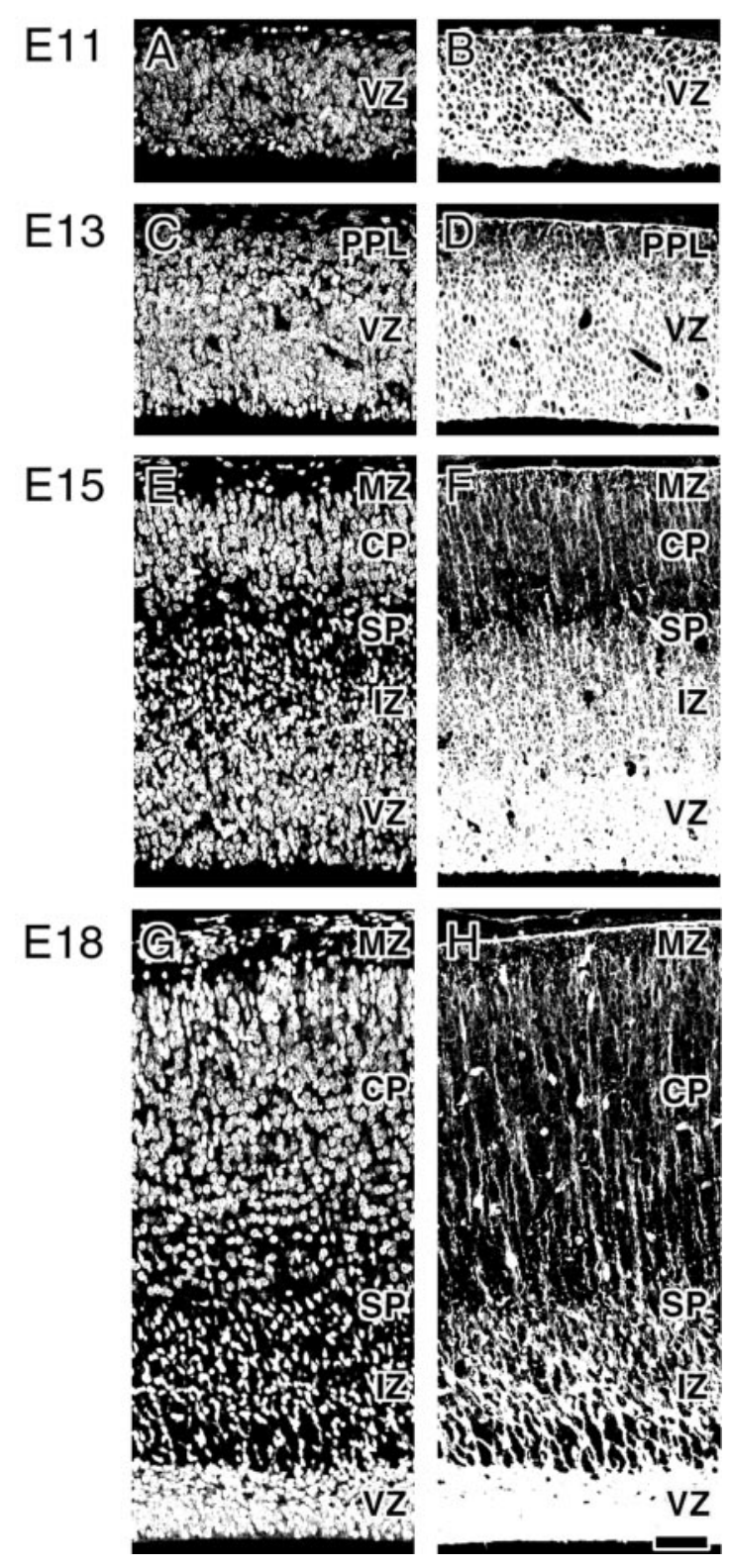

Figure 8. Developmental changes of the histology $(A, C, E, G)$ and 3PGDH immunofluorescence $(B, D, F, H)$ in the cerebral cortex at E11 $(A, B), \mathrm{E} 13(C, D), \mathrm{E} 15(E, F)$, and $\mathrm{E} 18(G, H)$. The ventricular zone $(V Z)$ displays strong immunolabeling for 3PGDH. Note that immunolabeling in radial processes is conspicuous in differentiating cortical zones, including the preplate $(P P L)$, marginal zone $(M Z)$, cortical plate $(C P)$, and intermediate zone (IZ). The pial surface is to the top. All photos are shown at the same magnification. For other abbreviations, see Figure 1 legend. Scale bar, $50 \mu \mathrm{m}$.

in multipolar cells distributed in the inner ONL as well as in the mantle zone of the olfactory bulb. In contrast, the outer ONL and peripheral structures surrounding olfactory nerves were only labeled for $3 \mathrm{PGDH}$. These results indicate that $3 \mathrm{PGDH}$ is expressed in non-neuronal cells that enfold olfactory nerve axons from the periphery through the ONL, i.e., the olfactory ensheathing glia.

\section{DISCUSSION}

In the developing and adult mouse brain, we have disclosed here a highly controlled cellular expression of the L-serine biosynthetic enzyme 3PGDH. The findings strongly favor our hypothesis that the nonessential amino acid L-serine is a key mediator of neuronglial metabolic interaction and functions as a glia-derived trophic factor for various central neurons.

\section{PGDH in neuroepithelial stem cells is preferentially transmitted to radial glia and later to astrocytes}

The development of the cerebral cortex is well characterized in the mouse (Caviness et al., 2000). The cerebral wall at E11 undergoes symmetric, exponential cell division to expand progenitor cells giving rise to prospective neurons and glia (Caviness and Takahashi, 1995; Rakic, 1995). The first postmitotic neurons appear and form the preplate at E12 (Derer and Derer, 1990; Bar et al., 2000). Then, radially migrating cortical neurons form the $\mathrm{CP}$ in an inside-out manner (Rakic, 1972) by invading the preplate and splitting it into the marginal zone to the top (later becoming layer I) and subplate to the bottom (layer V Ib). Consistent with the current view of corticogenesis, our brain materials followed such a developmental process. Using the brain materials, we found that cortical neuroepithelial cells were strongly and homogeneously immunopositive for 3PGDH. MAP-2-positive preplate neurons at E13 were immunonegative for 3PGDH. At E15 and thereafter, a remarkable increase of MAP-2-positive neurons took place in the $\mathrm{CP}$, where superficial young neurons retained low levels of $3 \mathrm{PGDH}$, but more mature neurons in the deeper CP had almost become devoid of it. In the adult, no significant labeling for 3PGDH was seen in neuronal cell bodies or dendrites of the cerebral cortex and other brain regions. Therefore, 3PGDH in neuroepithelial stem cells is lost, sooner or later, during neuronal differentiation. The absence of 3PGDH mRNA in the CP at E13 and E15 suggests its more rapid downregulation at the transcriptional level.

In contrast, 3PGDH was strongly detected at E13 and E15 in radial fibers traversing the preplate and $\mathrm{CP}$. At E18, cells with intense 3PGDH immunoreactivity appeared in the CP; they had radial fibers colabeled with the radial glia marker GLAST but not with the neuronal marker MAP-2. Radial fibers became obscure during the first postnatal week, and instead, most labeled cells were judged to be astrocytes by coexpression of GFAP and elaborate wrapping of synapses and capillaries. Even in the white matter, cells with high levels of 3PGDH were GFAP-positive astrocytes. Radial glia cells exist transiently during the stage of neurogenesis and neuronal migration and then migrate and transform into astrocytes and oligodendrocytes (Ramón y Cajal, 1911; Rakic, 1971b, 1972; Choi, 1981; Ono et al., 1997). Recently, it has been shown that radial glia cells are also neuronal precursors before the stage of exclusive astrocytic generation (Malatesta et al., 2000). Thus, it is reasonable to conclude that 3PGDH expression in neuroepithelial stem cells is downregulated with neuronal differentiation but is transmitted preferentially to the radial glia/ astrocyte lineage.

\section{Olfactory ensheathing glia expresses 3PGDH throughout development}

We found that the ONL exhibited high 3PGDH expression from E13 through to the adult stage and that the major expressing cell in the region is the olfactory ensheathing glia. The olfactory ensheathing glia differs from the astrocyte in many respects (Doucette, 1984, 1991; Marín-Padilla and Amieva, 1989; RamónCueto and Valverde, 1995). The olfactory ensheathing glia originates from the olfactory placode, and within the olfactory bulb its distribution is confined to the ONL and interstices between olfactory glomeruli. In contrast, astrocytes are of ventricular 

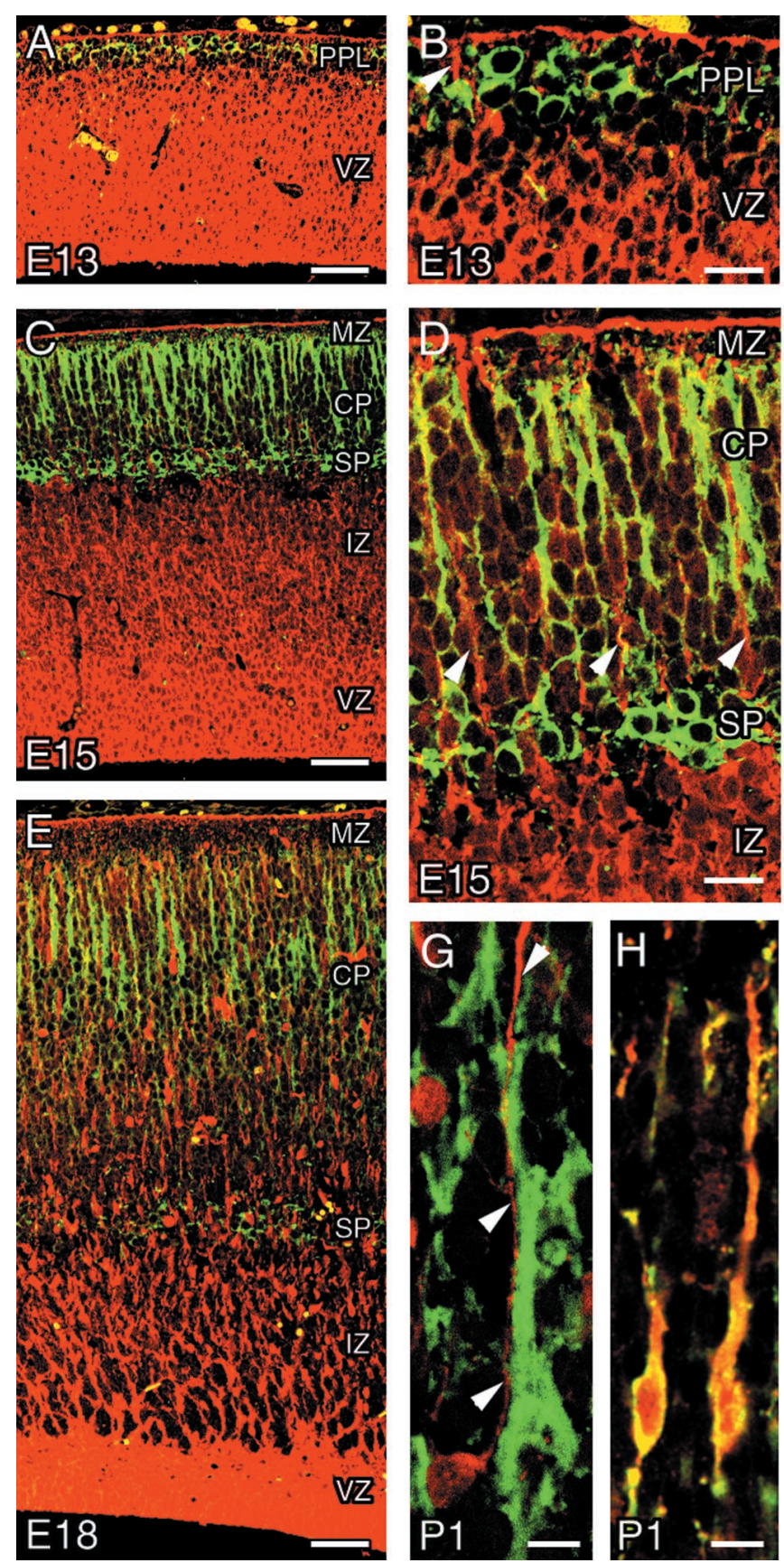

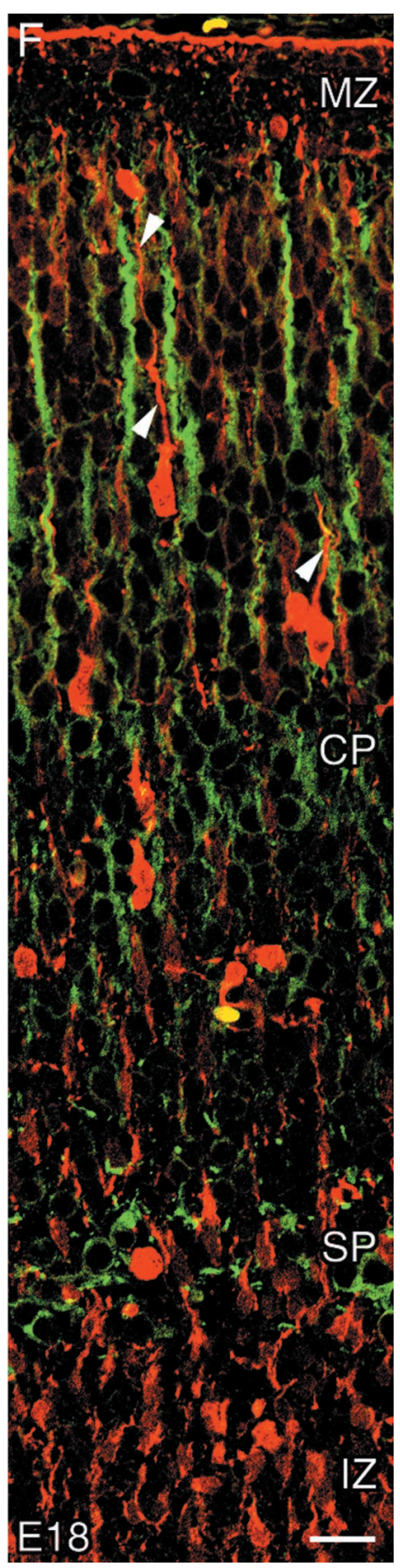

Figure 9. Double immunofluorescence in the cerebral cortex at $\mathrm{E} 13(A$, $B), \mathrm{E} 15(C, D), \mathrm{E} 18(E, F)$, and $\mathrm{P} 1(G$, $H) . A-G$, Double immunofluorescence for 3PGDH (red) and MAP-2 (green). Arrowheads indicate 3PGDH-positive radial fibers associating with MAP-2positive neuronal somata and processes. $H$, Double immunofluorescence for 3PGDH (red) and GLAST ( green). For other abbreviations, see Figure 1 legend. Scale bars: $A, C, E, 50 \mu \mathrm{m} ; B$, $D, F, 20 \mu \mathrm{m} ; G, H, 10 \mu \mathrm{m}$. origin, multipolar in shape, and distributed all over the olfactory bulb. Most conspicuously, olfactory ensheathing glia directly ensheathes olfactory nerves, whereas astrocytes never contact them (Doucette, 1991). Therefore, the olfactory ensheathing glia is another neural cell that expresses 3PGDH at high levels after the stage of neurogenesis.

\section{Functional relevance of distinct cellular expression of 3PGDH}

Eventually, the present cytochemical results suggest that, after neurogenesis, L-serine and its derivatives are synthesized preferentially by the radial glia/astrocyte lineage and olfactory ensheathing glia, and further that adjacent neurons and other glia need to take them in to synthesize various L-serine-derived biomolecules. Why is the molecular machinery for L-serine biosyn- thesis provided so differently between neurons and glia and also among glial populations?

Metabolic support for cells vulnerable to energy loss

Glucose and oxygen are indispensable substrates for energy production in the brain (Clarke and Sokoloff, 1994). Deprivation of glucose and oxygen for only a few minutes, which happens in vivo after ischemia by stroke or heart attack, triggers neuronal death (Meldrum et al., 1985; Rothman and Olney, 1986; Choi, 1988). Culture studies elucidate that oligodendrocytes and microglia are also vulnerable to hypoglycemia and hypoxia, whereas astrocytes are resistant (Goldberg and Choi, 1993; Lyons and Kettenmann, 1998; McDonald et al., 1998). Astrocytes are thought to be the primary site of glucose uptake from the circulation (Tsacopoulos and Magistretti, 1996), active glycolysis (Lopes-Cardozo et al., 

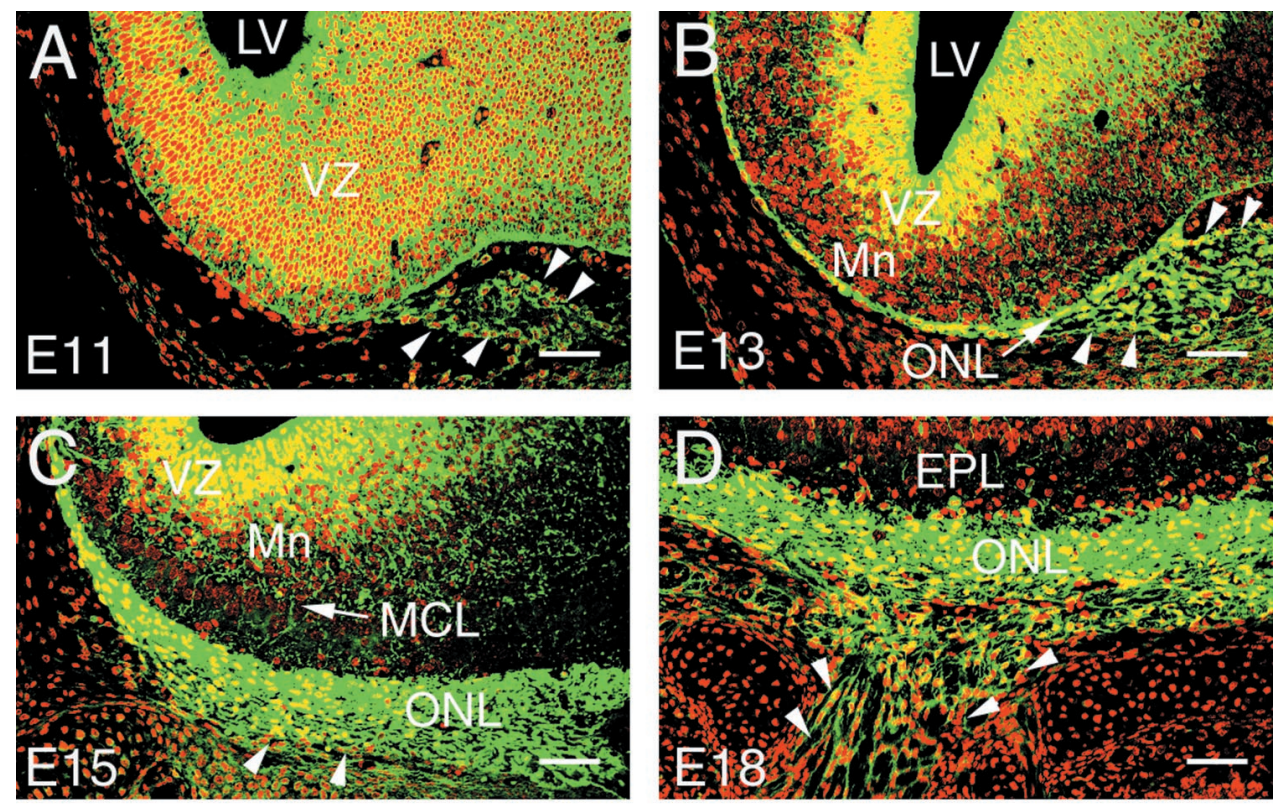

Figure 10. Double-labeling studies in the olfactory bulb at $\mathrm{E} 11(A), \mathrm{E} 13(B), \mathrm{E} 15$ $(C)$, and $\mathrm{E} 18(D-G) . A-D, 3$ PGDH immunofluorescence (green) and nuclear staining with propidium iodide $(r e d)$. In addition to the ventricular zone ( $V Z), 3 \mathrm{PGDH}$ is detected along cellular streams running through peripheral tissues (arrowheads), and they become the olfactory nerve layer $(O N L)$ after reaching the olfactory bulb. $E, F$, Double immunofluorescence for 3PGDH (red) and MAP-2 ( $E$, green), GAP-43 ( $F$, green $)$, or GLAST $(G$, green $)$. The rostral is to the left , and the dorsal is to the top. For other abbreviations, see Figure 1 legend. Scale bars, $50 \mu \mathrm{m}$.
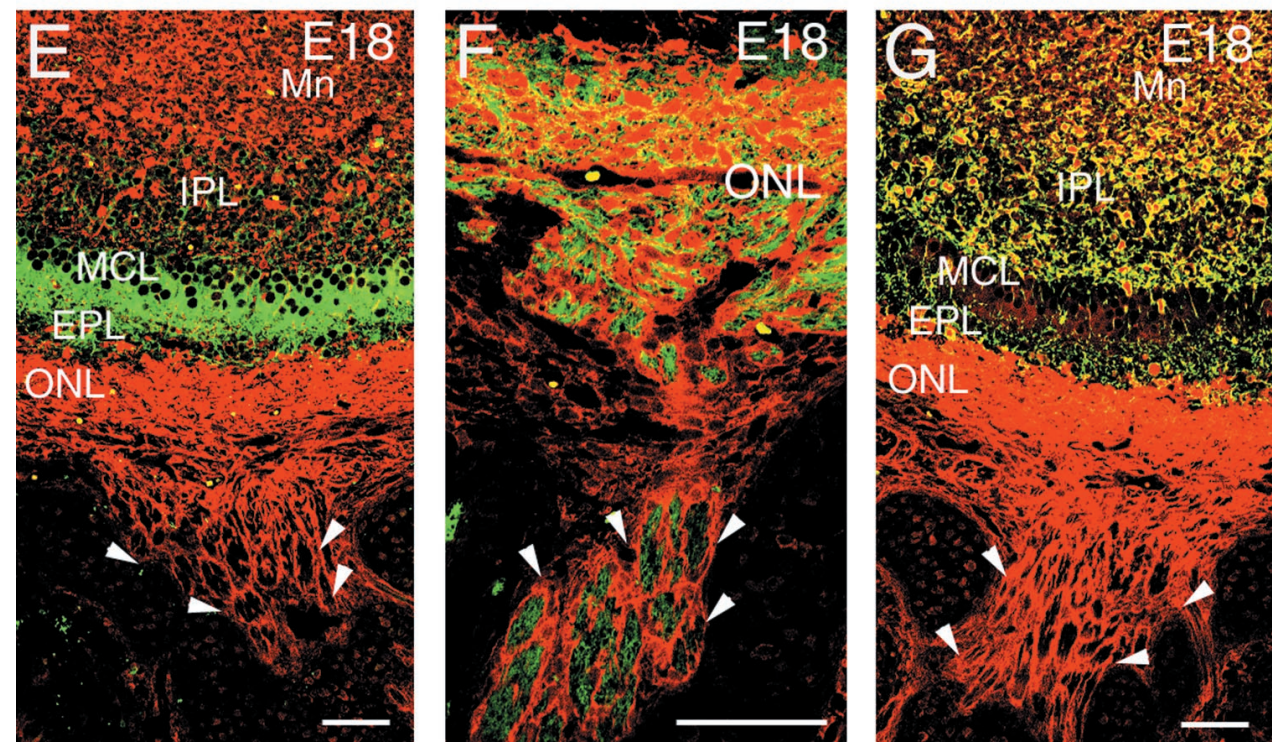

1986; Pellerin and Magistretti, 1996), and release of glycolytic intermediates, such as pyruvate and lactate (Tsacopoulos and Magistretti, 1996). Moreover, astrocytes contain abundant glycogen as an intracellular energy store (Hamprecht and Dringen, 1995), liberate glucose-1-phosphate from the stored glycogen (Reinhart et al., 1990), can maintain ion gradients under hypoxia and ischemia (Rose et al., 1998), and are also resistant to glutamatergic excitotoxicity (Choi and Rothman, 1990). These characteristics, together with intimate association with various neuronal elements, make it conceivable that the astrocyte is the most suitable neural cell for the synthesis of L-serine and its derivatives and for their supply to adjacent cells. Furthermore, the lack or scarcity of 3PGDH would be beneficial for cells that are vulnerable to energy loss, because the availability of these astrocytederived metabolites may save their own glycolytic intermediates preferentially for energy production, ensuring cell survival and function.

\section{Membrane lipid synthesis during cytodifferentiation}

Because L-serine is a precursor for membrane lipid synthesis, such as phospholipids and sphingolipids, the demands will in- crease during neuronal cytodifferentiation when the cell surface expands dynamically. Significant upregulation of 3PGDH was observed in neither differentiating cortical neurons nor Purkinje cells during active dendritogenesis (Furuya et al., 2000). Moreover, olfactory nerve axons that continue to regenerate throughout life (Graziadei and Graziadei, 1979; Graziadei and Monti Graziadei, 1980; Calof and Chikaraishi, 1989) were devoid of 3 PGDH expression. Instead, high levels of 3PGDH were consistently observed in particular glia cells associated with these neuronal elements, i.e., radial glia/astrocytes and olfactory ensheathing glia. Radial glia cells contact with migrating neurons, growing dendrites, and elongating axons (Rakic, 1971a, 1972; Hatten, 1990; Pearlman and Sheppard, 1996; Yamada et al., 2000). Furthermore, implants of the olfactory ensheathing glia show striking growth-promoting activities for regenerating axons, even in the adult CNS (Li et al., 1997; Ramón-Cueto et al., 2000). In this respect, it is assumed that these glia cells supply L-serine and its derivatives to differentiating neurons and neurites to support local membrane synthesis at a minimal loss of glucose for energy production. This in vivo metabolic relationship may underlie 
neurite outgrowth-promoting activity on cultured neurons by supplement of L-serine, glycine, or ceramide (Schwarz and Futerman, 1997; Furuya et al., 1998; Mitoma et al., 1998a,b).

Galactosylceramide and its sulfated derivative, sulfatide, are the sphingoglycolipids enriched in the myelin (Kanfer, 1995). Thus, the requirement of L-serine should also increase greatly in oligodendrocytes during myelin formation. In rodents, various myelin genes are upregulated during the second and third postnatal weeks (Sorg et al., 1987; Kanfer et al., 1989). However, in the corpus callosum of P14-P21 as well as the adult, cells highly expressing 3PGDH were GFAP-positive astrocytes. Oligodendrocytes did possess 3PGDH immunoreactivity in perikarya, but we did not detect it in their paranodal processes or mesaxons. Furthermore, no significant upregulation was observed in PLP mRNA-positive oligodendrocytes during the stage of active myelination. In the vicinity of Ranvier's node, 3PGDH was detected in astrocytic perinodal processes. From these results, we assume that oligodendrocytes may use, at least in part, astrocyte-derived L-serine and its derivatives for the formation and maintenance of myelin.

\section{D-Serine biosynthesis}

D-Serine is present in high levels in the mammalian brain (Hashimoto et al., 1992; Nagata et al., 1994; Schell et al., 1995, 1997) and is formed from L-serine by serine racemase (Wolosker et al., 1999a). Serine racemase is selectively expressed by protoplasmic astrocytes in the gray matter, such as cerebellar Bergmann glia and cortical astrocytes (Wolosker et al., 1999a,b). Thus, 3PGDH appears to coexist with serine racemase in these astrocytes. It has recently been reported that $\mathrm{D}$-serine binds to the glycine site of NMDA-type glutamate receptors (Mothet et al., 2000), which play multifarious roles in synapse development, synaptic plasticity, and memory and learning (Johnson and Ascher, 1987; Nakanishi et al., 1998). Therefore, astrocytic 3PGDH, in cooperation with serine racemase, may be involved in brain function and development by producing the coagonist D-serine for NMDA receptor activation.

In future studies, animal models with conditionally regulated 3PGDH will be important to further exploration of our hypothesis that distinct cellular regulation for L-serine biosynthesis is a fundamental mechanism for normal brain development and function.

\section{REFERENCES}

Achouri Y, Rider MH, Schaftingen EV, Robbi M (1997) Cloning, sequencing and expression of rat liver 3-phosphoglycerate dehydrogenase. Biochem J 323:365-370.

Altman J (1972) Postnatal development of the cerebellar cortex in the rat. II. Phases in the maturation of Purkinje cells and of the molecular layer. J Comp Neurol 145:399-463.

Bar I, de Rouvroit CL, Goffinet AM (2000) The reelin-signaling pathway and mouse cortical development. In: Mouse brain development (Goffinet AM, Rakic P, eds), pp 255-292. New York: Springer.

Calof AL, Chikaraishi DM (1989) Analysis of neurogenesis in a mammalian neuroepithelium: proliferation and differentiation of an olfactory neuron precursor in vitro. Neuron 3:115-127.

Caviness VS, Takahashi T (1995) Proliferative events in the cerebral ventricular zone. Brain Dev 17:159-163.

Caviness VS, Takahashi T, Nowakowski RS (2000) Neurogenesis and the early events of the neocortical histogenesis. In: Mouse brain development (Goffinet AM, Rakic P, eds), pp 107-143. New York: Springer.

Choi BH (1981) Radial glia of developing human fetal spinal cord: Golgi, immunohistochemical and electron microscopic study. Brain Res 227:249-267.

Choi DW (1988) Calcium-mediated neurotoxicity: relationship to specific channel types and role in ischemic damage. Trends Neurosci 11:465-469.

Choi DW, Rothman SM (1990) The role of glutamate neurotoxicity in hypoxic-ischemic neuronal death. Annu Rev Neurosci 13:171-182.
Clarke DD, Sokoloff L (1994) Circulation and energy metabolism of the brain. In: Basic neurochemistry: molecular, cellular, and medical aspects (Siegel G, Agranoff BW, Albers RW, Molinoff PB, eds), pp 645-680. New York: Raven.

Davis JL, Fallon HJ (1970) Studies on the role of 3-phosphoglycerate dehydrogenase in the regulation of serine biosynthesis in rat liver. J Biol Chem 245:5838-5846.

de Koning TJ, Duran M, Dorland L, Gooskens R, Van Schaftingen E, Jaeken J, Blau N, Berger R, Poll-The BT (1998) Beneficial effects of L-serine and glycine in the management of seizures in 3-phosphoglycerate dehydrogenase deficiency. Ann Neurol 44:261-265.

de Koning TJ, Poll-The BT, Jaeken J (1999) Continuing education in neurometabolic disorders-serine deficiency disorders. Neuropediatrics 30:1-4.

Derer P, Derer M (1990) Cajal-Retzius cell ontogenesis and death in mouse brain visualized with horseradish peroxidase and electron microscopy. Neuroscience 36:839-856.

Doucette JR (1984) The glial cells in the nerve fiber layer of the rat olfactory bulb. Anat Rec 210:385-391.

Doucette R (1991) PNS-CNS transitional zone of the first cranial nerve. J Comp Neurol 312:451-466.

Furuya S, Mitoma J, Makino A, Hirabayashi Y (1998) Ceramide and its interconvertible metabolite sphingosine function as indispensable lipid factors involved in survival and dendritic differentiation of cerebellar Purkinje cells. J Neurochem 71:366-377.

Furuya S, Tabata T, Mitoma J, Yamada K, Yamasaki M, Makino A, Yamamoto T, Watanabe M, Kano M, Hirabayashi Y (2000) L-serine and glycine serve as major astroglia-derived trophic factors for cerebellar Purkinje neurons. Proc Natl Acad Sci USA 97:11528-11533.

Gage FH (2000) Mammalian neural stem cells. Science 287:1433-1438.

Goldberg MP, Choi DW (1993) Combined oxygen and glucose deprivation in cortical cell culture: calcium-dependent and calciumindependent mechanisms of neuronal injury. J Neurosci 13:3510-3524.

Graziadei PP, Graziadei GA (1979) Neurogenesis and neuron regeneration in the olfactory system of mammals. I. Morphological aspects of differentiation and structural organization of the olfactory sensory neurons. J Neurocytol 8:1-18.

Graziadei PP, Monti Graziadei GA (1980) Neurogenesis and neuron regeneration in the olfactory system of mammals. III. Deafferentation and reinnervation of the olfactory bulb following section of the fila olfactoria in rat. J Neurocytol 9:145-162.

Grosche J, Matyash V, Moller T, Verkhratsky A, Reichenbach A, Kettenmann H (1999) Microdomains for neuron-glia interaction: parallel fiber signaling to Bergmann glial cells. Nat Neurosci 2:139-143.

Hamprecht B, Dringen R (1995) Energy metabolism. In: Neuroglia (Kettenmann H, Ransom BR, eds), pp 473-487. New York: Oxford UP

Hashimoto A, Nishikawa T, Hayashi T, Fujii N, Harada K, Oka T, Takahashi K (1992) The presence of free D-serine in rat brain. FEBS Lett 296:33-36.

Hatten ME (1990) Riding the glial monorail: a common mechanism for glial-guided neuronal migration in different regions of the developing mammalian brain. Trends Neurosci 13:179-184.

Ichihara A, Greenberg DM (1957) Further studies on the pathway of serine formation from carbohydrate. J Biol Chem 224:331-340.

Jaeken J, Detheux M, Van Maldergem L, Foulon M, Carchon H, Van Schaftingen E (1996) 3-Phosphoglycerate dehydrogenase deficiency: an inborn error of serine biosynthesis. Arch Dis Child 74:542-545.

Johnson JW, Ascher P (1987) Glycine potentiates the NMDA response in cultured mouse brain neurons. Nature 325:529-531.

Kanfer J, Parenty M, Goujet-Zalc C, Monge M, Bernier L, Campagnoni AT, Dautigny A, Zalc B (1989) Developmental expression of myelin proteolipid, basic protein, and $2^{\prime}, 3^{\prime}$-cyclic nucleotide $3^{\prime}$ phosphodiesterase transcripts in different rat brain regions. J Mol Neurosci 1:39-46.

Kanfer JN (1995) Lipid metabolism. In: Neuroglia (Kettenmann H, Ransom BR, eds), pp 523-531. New York: Oxford UP.

Klomp LW, de Koning TJ, Malingre HE, van Beurden EA, Brink M, Opdam FL, Duran M, Jaeken J, Pineda M, van Maldergem L, Poll-The BT, van den Berg IE, Berger R (2000) Molecular characterization of 3-phosphoglycerate dehydrogenase deficiency-A neurometabolic disorder associated with reduced L-serine biosynthesis. Am J Hum Genet 67:1389-1399.

Li Y, Field PM, Raisman G (1997) Repair of adult rat corticospinal tract by transplants of olfactory ensheathing cells. Science 277:2000-2002.

Lopes-Cardozo M, Larsson OM, Schousboe A (1986) Acetoacetate and glucose as lipid precursors and energy substrates in primary cultures of astrocytes and neurons from mouse cerebral cortex. J Neurochem 46:773-778.

Lowry OH, Rosebrough NJ, Farr AL, Randall RJ (1951) Protein measurement with the folin phenol reagent. J Biol Chem 193:265-275.

Lyons SA, Kettenmann H (1998) Oligodendrocytes and microglia are selectively vulnerable to combined hypoxia and hypoglycemia injury in vitro. J Cereb Blood Flow Metab 18:521-530.

Malatesta P, Hartfuss E, Götz M (2000) Isolation of raidal glial cells by 
fluorescent-activated cell sorting reveals a neuronal lineage. Development 127:5253-5263.

Marín-Padilla M, Amieva MR (1989) Early neurogenesis of the mouse olfactory nerve: Golgi and electron microscopic studies. J Comp Neurol 288:339-352.

McDonald JW, Althomsons SP, Hyrc KL, Choi DW, Goldberg MP (1998) Oligodendrocytes from forebrain are highly vulnerable to AMPA/kainate receptor-mediated excitotoxicity. Nat Med 4:291-297.

Meldrum B, Evans M, Griffiths T, Simon R (1985) Ischaemic brain damage: the role of excitatory activity and of calcium entry. $\mathrm{Br} \mathrm{J}$ Anaesth 57:44-46.

Mitoma J, Furuya S, Hirabayashi Y (1998a) A novel metabolic communication between neurons and astrocytes: non-essential amino acid L-serine released from astrocytes is essential for developing hippocampal neurons. Neurosci Res 30:195-199.

Mitoma J, Kasama T, Furuya S, Hirabayashi Y (1998b) Occurrence of an unusual phospholipid, phosphatidyl-L-threonine, in cultured hippocampal neurons. Exogenous L-serine is required for the synthesis of neuronal phosphatidyl-L-serine and sphingolipids. J Biol Chem 273:19363-19366.

Mothet JP, Parent AT, Wolosker H, Brady RO, Linden DJ, Ferris CD, Rogawski MA, Snyder SH (2000) D-serine is an endogenous ligand for the glycine site of the $N$-methyl-D-aspartate receptor. Proc Natl Acad Sci USA 97:4926-4931.

Nagata Y, Horiike K, Maeda T (1994) Distribution of free D-serine in vertebrate brains. Brain Res 634:291-295.

Nakanishi S, Nakajima Y, Masu M, Ueda Y, Nakahara K, Watanabe D, Yamaguchi S, Kawabata S, Okada M (1998) Glutamate receptors: brain function and signal transduction. Brain Res Brain Res Rev 26:230-235.

Ono K, Yasui Y, Rutishauser U, Miller RH (1997) Focal ventricular origin and migration of oligodendrocyte precursors into the chick optic nerve. Neuron 19:283-292.

Pearlman AL, Sheppard AM (1996) Extracellular matrix in early cortical development. Prog Brain Res 108:117-134.

Pellerin L, Magistretti PJ (1996) Excitatory amino acids stimulate aerobic glycolysis in astrocytes via an activation of the $\mathrm{Na}+/ \mathrm{K}+$ ATPase. Dev Neurosci 18:336-342.

Rakic P (1971a). Guidance of neurons migrating to the fetal monkey neocortex. Brain Res 33:471-476.

Rakic P (1971b) Neuron-glia relationship during granule cell migration in developing cerebellar cortex. A Golgi and electronmicroscopic study in Macacus Rhesus. J Comp Neurol 141:283-312.

Rakic P (1972) Mode of cell migration to the superficial layers of fetal monkey neocortex. J Comp Neurol 145:61-83.

Rakic P (1995) A small step for the cell, a giant leap for mankind: a hypothesis of neocortical expansion during evolution. Trends Neurosci 18:383-388.

Ramón-Cueto A, Valverde F (1995) Olfactory bulb ensheathing glia: a unique cell type with axonal growth-promoting properties. Glia 14:163-173.

Ramón-Cueto A, Cordero MI, Santos-Benito FF, Avila J (2000) Functional recovery of paraplegic rats and motor axon regeneration in their spinal cords by olfactory ensheathing glia. Neuron 25:425-435.
Ramón y Cajal S (1911) Histologie du Système Nerveux de l'Homme et des Vertébrés, Tome 2. Reprint (Paris: Maloine, 1952).

Reinhart PH, Pfeiffer B, Spengler S, Hamprecht B (1990) Purification of glycogen phosphorylase from bovine brain and immunocytochemical examination of rat glial primary cultures using monoclonal antibodies raised against this enzyme. J Neurochem 54:1474-1483.

Rose CR, Waxman SG, Ransom BR (1998) Effects of glucose deprivation, chemical hypoxia, and simulated ischemia on $\mathrm{Na}^{+}$homeostasis in rat spinal cord astrocytes. J Neurosci 18:3554-3562.

Rothman SM, Olney JW (1986) Glutamate and the pathophysiology of hypoxic-ischemic brain damage. Ann Neurol 19:105-111.

Savoca R, Ziegler U, Sonderegger P (1995) Effects of L-serine on neurons in vitro. J Neurosci Methods 61:159-167.

Schell MJ, Molliver ME, Snyder SH (1995) D-serine, an endogenous synaptic modulator: localization to astrocytes and glutamate-stimulated release. Proc Natl Acad Sci USA 92:3948-3952.

Schell MJ, Brady RO, Molliver ME, Snyder SH (1997) D-serine as a neuromodulator: regional and developmental localizations in rat brain glia resemble NMDA receptors. J Neurosci 17:1604-1615.

Schwarz A, Futerman AH (1997) Distinct roles for ceramide and glucosylceramide at different stages of neuronal growth. J Neurosci 17:2929-2938.

Shibata T, Yamada K, Watanabe M, Ikenaka K, Wada K, Tanaka K, Inoue Y (1997) Glutamate transporter GLAST is expressed in the radial glia-astrocyte lineage of developing mouse spinal cord. J Neurosci 17:9212-9219.

Smith QR (2000) Transport of glutamate and other amino acids at the blood-brain barrier. J Nutr 130(4S Suppl):1016S-1022S

Snell K (1984) Enzymes of serine metabolism in normal, developing and neoplastic rat tissues. Adv Enzyme Regul 22:325-400.

Snyder SH, Kim PM (2000) D-amino acids as putative neurotransmitters: focus on D-serine. Neurochem Res 25:553-560.

Sorg BA, Smith MM, Campagnoni AT (1987) Developmental expression of the myelin proteolipid protein and basic protein mRNAs in normal and dysmyelinating mutant mice. J Neurochem 49:1146-1154.

Stryer L (1995) Biochemistry, Ed 4. New York: Freeman.

Tanaka S, Suzuki K, Watanabe M, Matsuda A, Tone S, Koike T (1998) Upregulation of a new microglial gene, mrf-1, in response to programmed neuronal cell death and degeneration. J Neurosci 18:6358-6369.

Tsacopoulos M, Magistretti PJ (1996) Metabolic coupling between glia and neurons. J Neurosci 16:877-885.

Verleysdonk S, Hamprecht B (2000) Synthesis and release of L-serine by rat astroglia-rich primary cultures. Glia 30:19-26.

Wolosker H, Sheth KN, Takahashi M, Mothet JP, Brady RO, Ferris CD, Snyder SH (1999a) Purification of serine racemase: biosynthesis of the neuromodulator D-serine. Proc Natl Acad Sci USA 96:721-725.

Wolosker H, Blackshaw S, Snyder SH (1999b) Serine racemase: a glial enzyme synthesizing D-serine to regulate glutamate- $N$-methyl-Daspartate neurotransmission. Proc Natl Acad Sci USA 96:13409-13414.

Yamada K, Fukaya M, Shibata T, Kurihara H, Tanaka K, Inoue Y, Watanabe M (2000) Dynamic transformation of Bergmann glial fibers proceeds in correlation with dendritic outgrowth and synapse formation of cerebellar Purkinje cells. J Comp Neurol 418:106-120. 